Revised, April 2005

\title{
Directional Asymmetries in the Morphology and Phonology of Words, with Special Reference to Bantu
}

\author{
Larry M. Hyman \\ University of California, Berkeley
}

This paper is concerned with two types of word-level asymmetries and their interaction: leftright asymmetries and stem-word asymmetries. Two left-right asymmetries are examined from a wide range of languages, one morphological (the predominance of suffixation over prefixation), one phonological (the preference for anticipatory over perseverative phonology). Since phonological processes are often triggered by features which originate in roots, a second asymmetry is also addressed: the tendency for suffixes to be more tightly bound to roots than prefixes. Asymmetries between stem- vs. word phonology are examined in Bantu, where suffixes are incorporated into a derived stem domain, from which prefixes are typically excluded. This root+suffix stem domain is shown to be the locus of phonological activity in Proto-Bantu and throughout the large Bantu family, which divides into two typological zones: (i) Northwest Bantu languages, which impose a maximal size condition and stringent consonant distribution constraints on stems; (ii) Central Bantu languages, which do not restrict the size or consonant distribution of stems, but frequently impose a minimal size condition on words. The study presents a number of generalizations concerning such asymmetries and identifies questions for future research.

\section{Introduction}

Given the range of variation and the logical options exploited by the world's languages, one might conclude that the morphological structure and the phonological realization of words are remarkably symmetric. In terms of morphology, a root can be expanded on either side: both prefixes and suffixes are widely attested in the world's languages. In terms of phonology, either edge of a word can be the locus of special marking. In addition, internal positions for morphological or phonological marking can be calculated from either the beginning or the end of a word, e.g. for infix-placement, featural affixation, stress-assignment, and so forth. While this symmetry is non-surprising, perhaps even welcome from a formal point of view, beneath it lie a number of asymmetries that have been gradually coming to light. 
The purpose of this paper is to provide an overview of two types of word-level asymmetries and their interaction: left-right asymmetries and stem-word asymmetries. While the first asymmetry will be examined via examples from different languages, the Bantu family of ca. 500 languages will be examined for addressing stem-word asymmetries.

The paper is organized as follows. In §2 I address two left-right asymmetries, one morphological, one phonological: the predominance of suffixation over prefixation and the predominance of anticipatory over perseverative phonology. $\S 3$ examines whether these asymmetries are also in effect in prosodic morphology. $\S 4$ shows how root-controlled phonology interacts (and potentially conflicts) with anticipatory phonology, while $\S 5$ addresses left-right asymmetries in stem vs. word domains, with particular reference to Bantu. $\S 6$ concludes with a brief discussion of prefix-stem fusion in light of the different findings and proposals. ${ }^{1}$

\section{Left-right asymmetries}

As indicated in the preceding paragraph, the inventory of word-level phenomena is superficially symmetric. However, left-right asymmetries such as those listed in (1) have been noted in literature:

(1) Oft-noted left-right asymmetries

a. prefixes vs. suffixes

i. morphology: suffixes are more prevalent than prefixes

ii. phonology: suffixes are more "cohering" than prefixes

b. anticipatory vs. perseverative phonology

i. segmental: anticipatory phonology is more prevalent than perseverative ii. tonal: perseverative phonology is more prevalent than anticipatory

c. pre-tonic vs. post-tonic phonology

i. stress: post-stress syllables are weaker, more prone to reduction than pre-stress ii. harmonies: post-radical syllables are more prone to harmonies than pre-radical

d. initial vs. final edge-marking

i. phonology: initial strengthening/preservation vs. final weakening/loss ii. morphology: stem-initiality vs. word-finality

The goal of the following subsections is to examine the above and other potential asymmetries. In $\S 3$ we will consider how these asymmetries contribute to the understanding of stem- and word-domains in phonology. 


\subsection{Preponderance of suffixation over prefixation}

It has often been noted that suffixing is particularly prevalent across languages: "Of the three types of affixing - the use of prefixes, suffixes and infixes—suffixing is much the commonest. Indeed, it is a fair guess that suffixes do more of the formative work of language than all other methods combined." (Sapir 1921:67) Greenberg (1966:92) notes that languages can have both prefixes and suffixes, but goes on to say that there are more languages lacking the former than the latter: "As between prefixing and suffixing, there is a general predominance of suffixing. Exclusively suffixing languages are fairly common, while exclusively prefixing languages are quite rare." (Greenberg 1966:92)

Over the past two centuries there have been numerous attempts to relate direction of affixation with other morphological or phonological properties (see Plank 1988 for a history and appraisal of this work). More recently a number of scholars have directly addressed the question of why suffixing should be preferred over prefixing. Hawkins \& Cutler (1988:285), for instance, attempt to align the direction of affixation with the head/non-head order in the syntax. They find that three out of four affix-head alignments are richly attested in the world's languages:

(2) Three-out-of-four correlations of affix-alignment with head order

\begin{tabular}{l|c|c|c}
\multicolumn{1}{c}{} & \multicolumn{2}{c}{ Prefixes } & \multicolumn{2}{c}{ Suffixes } \\
\cline { 2 - 3 }$\{\mathrm{VO}, \mathrm{Pr}+\mathrm{NP}\}$ & $\checkmark$ & $\checkmark$ & $\begin{array}{l}\text { head-initial syntax co-occurs with prefixes \& suffixes } \\
\text { head-final syntax co-occurs with suffixes }\end{array}$ \\
\cline { 2 - 3 } & $\mathrm{O}, \mathrm{NP}+\mathrm{Po}\}$ & $\checkmark$ &
\end{tabular}

In (2) head-order is determined on the basis of where the object $(\mathrm{O})$ is with respect to the verb $(\mathrm{V})$ and whether the language is prepositional $(\mathrm{Pr})$ or postpositional $(\mathrm{Po})$. The claim is that many head-initial and head-final languages are exclusively suffixing, while head-final languages are overwhelmingly suffixing. Head-final prefixing languages are rare. To account for this " $3 / 4$ situation", Hawkins \& Cutler propose the following two principles:

(3) Suffix preference is explained by two principles

a. Syntax: Head-Ordering Principle (HOP)

b. Universal ranking: Suffixing $\gg$ Prefixing

First, they propose a Head-Ordering Principle (HOP): “The affix head of a word is ordered on the same side of its subcategorized modifier(s) as $\mathrm{P}$ is ordered relative to NP within PP, and as V is ordered relative to a direct object NP" (p.290). This gets us head-initial + prefixing and head-final + suffixing, 
but not head-initial + suffixing. A lot may depend on what counts as an affix vs. something else (e.g. clitic), but their study seems to reveal both a tendency in alignment-and a gap. For the latter they claim a default preference: suffixing is universally preferred over prefixing, i.e. Suffixing $>>$ Prefixing. In support of this they cite Hawkins \& Gilligan (1988), who indicate that languages show a clear suffix tendency for marking gender, case, indefiniteness, nominalization, number, mood, tense, aspect, valence, causative. Fewer notions appear to favor prefixation, one claimed such case being person agreement (Enrique-Arias 2002).

In subsequent discussions we will see other " $3 / 4$ situations", where three out of four logical combinations of two binary properties are attested. In each case the solution will be the same: One of the properties is specific and symmetric, the other is general and asymmetric. The latter is always available as a "default".

\subsection{Preponderance of anticipatory over perseverative phonology}

While the HOP reveals a relation between head-order and direction of affixation, we still need to account for why suffixing is universally preferred over prefixing. Functional explanations have fallen in two broad categories, roughly corresponding to speaker vs. listener advantages in word packaging and word processing (Greenberg 1957, Nooteboom 1981, Hawkins \& Cutler 1988, Beckman 1998, Smith 2002):

(4) Explanations for Suffixing $>>$ Prefixing

a. informational asymmetries: root $>>$ affix

b. temporal asymmetries: beginnings $>$ ends ( $>>$ middles)

First, there are informational asymmetries between roots and affixes: Whereas affixes (grammatical morphemes) are limited in number, roots (lexical morphemes) represent an open class. Not only do roots convey more meaning in the sense that there are more to choose from, but much more of what is marked affixally is redundant or can be inferred from context. The argument, therefore, is that by placing roots before affixes, new or salient information will be conveyed earlier. This correlates with the oft-noted greater salience of beginnings of words over ends (and, in turn, over middles). In fact, aligning a root with the left edge of a word may be especially desirable for processing purposes. As Hawkins \& Cutler (1988:306) put it: “We maintain that... speakers and listeners process stems before affixes.... Thus the 
fact that languages exhibit a suffixing preference... [even] when their remaining structural characteristics would predict the reverse, reflects the order of computation of stem and affix in processing." On the other hand, Bybee et al (1991:35) state that their cross-linguistic survey does not provide "evidence that this alleged processing preference encourages suffixation over prefixation". They "regard the affixation process as extremely complex, involving syntactic, phonetic, semantic and processing factors" and propose a Fossilized Syntax hypothesis: “...grams develop in the position in which their lexical ancestor was located". However, if correct, the preponderance of suffixation must indicate that postposed elements are more likely to develop into grammatical affixes than preposed.

Already Greenberg (1957:89) had noted that there is an important interplay with diachrony to consider (cf. Hall 1988). First, there is the issue of origin: being disfavored, prefixes are less likely to arise. Second, there is the issue of survival: once prefixes arise, being disfavored, they are more subject to loss. Greenberg further speculates that prefixes may be particularly vulnerable due to another leftright asymmetry which is strictly phonological:

(5) Another left-right asymmetry: Anticipation $>>$ Perseveration (lag)

a. segmental assimilations are claimed to be more frequently anticipatory than perseverative

b. this anticipatory tendency is said to conspire against prefixation

First, segmental assimilations are said to be more frequently anticipatory than perseverative: "In regular conditioned sound changes, the conditioning factor is far more frequently a sound which follows than one which precedes" (Greenberg 1957:90). Javkin (1979:75-76) confirms Greenberg's impression: “I examined 365 segmental assimilatory rules culled from 60 languages... documented in the Stanford Phonology Archive. 195 of these rules involved anticipatory assimilation of a segment to a following segment. 89 of these involved the perseverative assimilation of a segment to a preceding segment.... The conclusion must be that segmental assimilation is generally anticipatory...." Greenberg then conjectures that the tendency for assimilation to be anticipatory conspires against prefixes: “Once prefixes are established, the mechanism of various assimilative changes based on anticipation will result in what was originally a prefix, with a single fixed form, assuming various special alternants.... The climax of this development leads logically to an isolating form of speech in which the former prefixes have all been absorbed." (p.92) However, for this explanation to go through, it is necessary to show that suffixes are not subject to the same tendency to be "absorbed", especially as post-tonic, post-radical, and final 
elements tend to reduce more than pre-tonic, pre-radical and initial elements. Bybee et al (1991:34) test this hypothesis and find that "...our data do not support the view that the affixation imbalance may be explained by reference to anticipatory assimilation or increased reduction at the ends of words."

As an aside, it should be noted that I have characterized anticipation as a strictly segmental tendency, because tone—or at least tone spreading—has just the opposite property, as indicated in (6).

(6) Tone spreading is more perseverative than anticipatory

INPUT: Anticipatory Perseverative

$\mathrm{L}-\mathrm{H}$

$\mathrm{H}-\mathrm{L}$

\begin{tabular}{|c|c|}
\hline ? $\widehat{\mathrm{LH}}-\mathrm{H}$ & $\mathrm{L}-\widehat{\mathrm{LH}}$ \\
\hline ? $\mathrm{HL}-\mathrm{L}$ & $\mathrm{H}-\widehat{\mathrm{HL}}$ \\
\hline
\end{tabular}

L tone spreading is perseverative

$\mathrm{H}$ tone spreading is perseverative

As Hyman \& Schuh (1974:90) put it: “...tonal assimilations differ from segmental ones. The former are usually perseverative, while the latter are usually anticipatory. Thus, a rule palatalizing / $/ \mathrm{k}$ to $[\mathrm{c}$ ] before [i] is more frequent than a rule palatalizing / k/ to [č after [i]...." The perseverative nature of tone spreading is also confirmed by Javkin (1979). ${ }^{2}$

\section{Prosodic morphology}

In $§ 2$ we have established preferences for suffixal over prefixal morphology, and anticipatory over perseverative phonology. The question raised in the present section is whether these preferences also characterize prosodic morphology. In the following subsections I briefly consider featural affixes, infixation and reduplication.

\subsection{Featural affixes}

In this section we consider subsegmental or featural affixes (Akinlabi 1996, Zoll 1998). Just as full segment-size suffixes are preferred over prefixes, the same is true with non-tonal featural affixes.

Afro-Asiatic languages are well-known for their labial and palatal prosodies. Consider, for example, the following forms from Mafa, a Chadic language spoken in Cameroon:

(7) Suffixal labial and palatal prosodies in Mafa (Barreteau 1987, 1990; Ettlinger 2004)

$\begin{array}{rllll} & \text { verb } & \text { imperfective } & \text { perfective } & \\ \text { a. } & \text { nda } & \text { ndá-y } & \text { ndá-w } & \text { 'eat' } \\ & \text { gudza } & \text { gudza-y } & \text { gudza-w } & \text { 'tremble' } \\ \text { b. } & \text { pán } & \text { pén } & \text { pón } & \text { 'wash' } \\ & \text { tsap } & \text { čep } & \text { tsop } & \text { 'mud' } \\ & \text { nakad } & \text { neked } & \text { nok }{ }^{\text {wad }}{ }^{3} & \text { 'lick' }\end{array}$


Barreteau $(1987,1990)$ distinguishes two classes of verb bases: those which end in [a] vs. those which end in a consonant. As seen in (7a), the former take a segmental suffix -y in the imperfective, and a segmental suffix $-w$ in the perfective. However, in $(7 b)$, we see that when the verb base ends in a consonant, the respective labial and palatal features are fused into the base, potentially affecting both consonants and vowels. Although we can't tell from (7b), the $-\mathrm{w}$ and $-\mathrm{y}$ in $(7 \mathrm{a})$ make clear that the labial and palatal prosodies are suffixal in nature.

The suffixal nature of such prosodies is also seen in the oft-cited case of Chaha, a Semitic language spoken in Ethiopia:

(8) Labial prosody in Chaha (McCarthy 1983, Rose 1993)

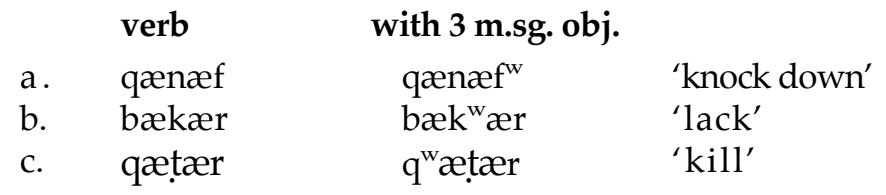

In Chaha, a third person masculine singular object is expressed by labializing the last labializable (i.e. non-coronal) consonant of the verb base. Although coronal consonants will be skipped over, we see that the calculation is done on a right-to-left basis, hence that we are dealing with a suffix.

Where it is possible to tell, such morphological prosodies as in Mafa and Chaha are typically suffixal (cf. also the relation to "umlaut"). Prefixal analogues are most likely to have only local effects, resembling either metathesis or infixing. Such is the case in Noni in (9).

(9) Labial prefix in Noni, a Bantoid language spoken in Cameroon (Hyman 1981)

\begin{tabular}{|c|c|c|c|c|}
\hline pre-Noni & & class 3 & & cf. pl. class 4 \\
\hline *u-tén & $>$ & twén & 'vine branch' & tén \\
\hline${ }^{*} u-g \varepsilon \grave{\varepsilon}$ & $>$ & gweغ̀ & 'ceiling' & gદદ \\
\hline *u-ngénsé & $>$ & ngwénsé & 'earthworm' & ygénsé \\
\hline
\end{tabular}

This is clearly related to the failure of prefixes to condition vowel harmony (see Hyman, in press, and references cited therein). ${ }^{4}$

\subsection{Infixes}


The possibility of viewing Noni as having featural infixation raises the more general question of how full-segment infixes fit into the asymmetries we have been discussing. Based on the appendix in Yu (2003), we see in (14) that infixation reveals a distinct left-edge bias:

(10) Left- vs. right-edge infixing (Yu 2003)

a. \# of cases of infixing calculated from left edge: 58

b. \# of cases of infixing calculated from right edge: 16

c. \# of cases of infixing which are ambiguous: $\quad 7$

d. \# of cases of infixing calculated on other basis: 6

Yu was quite aware of this skewing. The following, which appeared in the text of an earlier draft of Yu (2003), considers both infixes and internal reduplication: “...cases of infixes appearing toward to the initial portion of the root are far more numerous than those appearing toward the final portion.... of the 128 cases [including internal reduplication], ninety-six of them involve initial infixation, while only twenty-eight cases can be considered final. The number of cases of initial-oriented infixation is almost three times more common than the final-oriented infixation cases. This asymmetry is not expected at all in light of the mounting psycholinguistic and typological evidence for the preference for suffixes over prefixes in the world's languages."

It may be that infixes are more likely to develop from prefixes than from suffixes. Hawkins \& Cutler (1988) go only as far as stating that infixes are rare because they interrupt the stem. However, this left-bias conforms with their basic claim better than a right-bias: Speakers not only process stems before affixes, but in so doing sometimes anticipate the stem-initial, skipping over a prefix, which then gets fused into the stem. If correct, this would also correspond with an apparent anticipatory bias in speech errors (Hansson 2001).

\subsection{Reduplication}

Reduplication has not been surveyed for this study. However, two claims have been made in the literature concerning the position of reduplicants relative to their base. Hyman, Inkelas \& Sibanda (1998) suggest that reduplicants tend to appear on the opposite side of the root from the direction of affixation: a reduplicant tends to be prefixed if the relevant domain (stem, word) is predominantly suffixing; contrarily, a reduplicant tends to be suffixed if the relevant domain is predominantly prefixing. The rationale is a morphological one: with opposite-side reduplicants, the affixes fall 
outside the reduplicated base: prefixes+base+reduplicant, reduplicant+base+suffixes. Same-side reduplicants, on the other hand, can easily obscure the morphological structure.

A second claim, made by Nelson (2002), is that reduplication tends to be prefixal in general. Taken together, the two claims predict another " $3 / 4$ situation" as follows:

(11) Three-out-of-four correlations of affix-alignment with reduplicant-alignment

\begin{tabular}{l|c|c|}
\multicolumn{1}{c}{} & \multicolumn{1}{c}{ RED-Base } & \multicolumn{1}{c}{ Base-RED } \\
\cline { 2 - 3 } Prefixing & $\checkmark$ & $\checkmark$ \\
Suffixing & $\checkmark$ & $?$ \\
\cline { 2 - 3 } & &
\end{tabular}

As seen, prefixal reduplication should be free to occur whether the domain is predominantly prefixing or suffixing, whereas suffixal reduplication should be disproportionately disfavored when the domain is predominantly suffixing. Hyman, Inkelas \& Sibanda (1998) cite examples showing that Bantu stemreduplication is prefixal (because the stem consists of a root + suffixes), whereas word-level reduplication is suffixal (since the word consists of prefixes + a stem). All of this presupposes that the reduplicant can be clearly identified, which is not always the case (Inkelas \& Zoll 2005).

\section{Root control}

An important counter-balance to the anticipatory tendency of segmental processes is root-control (Clements 1981). ${ }^{5}$ As indicated in (12), both prefixes and suffixes frequently assimilate to roots:

(12) Important counter-balance to anticipatory tendency: root-control (Clements 1981)

\begin{tabular}{|c|c|c|c|}
\hline \multirow{3}{*}{$\begin{array}{l}\text { Prefix- Root } \\
\text { Root-Suffix }\end{array}$} & Anticipatory & Perseverative & \multirow{3}{*}{$\begin{array}{l}\text { anticipatory phonology from root to prefix } \\
\text { bidirectional phonology between suffix \& root }\end{array}$} \\
\hline & $\sqrt{J}$ & $?$ & \\
\hline & 1 & 1 & \\
\hline
\end{tabular}

We again have another $3 / 4$ situation: segmental processes are bidirectional between roots and suffixes, but unidirectional between roots and prefixes. We explain this by treating root-control as the specific asymmetric constraint and anticipation as the general default. What is least expected are cases where prefixes trigger phonological changes on roots. ${ }^{6}$ At least the following phenomena show the combined 3/4 effects of root-control + anticipation: ${ }^{7}$ 


\section{1. $\mathrm{V}+\mathrm{V}$ elision and assimilation}

When two vowels $V_{1} V_{2}$ occur in sequence either within or across a domain, there is a distinct anticipatory bias in both elision and assimilatory processes: “... $\mathrm{V}_{1}$ elision is far more common and productive than elision of $\mathrm{V}_{2}$ " (Casali 1997:496). On the other hand, suffixal V2 elision may occur when preceded by a root $V_{1}$. The asymmetry is stated as follows by Casali (1997:496): “Only $\mathrm{V}_{1}$ elision generally occurs at the boundary between a (minimally) CV prefix and a root.... At the boundary between a root and a suffix, either $\mathrm{V}_{1}$ or $\mathrm{V}_{2}$ elision is possible...." What is less commonly found, therefore, is the fourth possibility: elision of a root $V_{2}$.

\section{2. $\mathrm{C}+\mathrm{C}$ elision and assimilation}

As in the case of vowels, $C_{1} C_{2}$ elision and assimilation are generally anticipatory (Ohala 1990, Steriade 2001). When there is total assimilation, the expected realization is thus $C_{2} C_{2}$ (Italian *octo > otto), rather than $\mathrm{C}_{1} \mathrm{C}_{1}$. Similarly, $\mathrm{N}+\mathrm{C}$ sequences frequently undergo anticipatory homorganic nasal assimilation, rather than perseverative homorganic oral assimilation. This directional bias may, however, be overriden by root control (Borowsky 2000, Hyman 2001). Thus, the examples in (8) from Noni show the progressive suffix /-tè/ assimilating to a preceding velar nasal, rather than the reverse:

(13) Perseverative place assimilation of the progressive /-tè/ suffix in Noni (Hyman 2001)

\begin{tabular}{|c|c|c|c|}
\hline INPUT: & / cin-tè / & / kay-tè / & 'be trembling' / 'be frying' \\
\hline expected: & ${ }^{*}$ ci:n-tè & ${ }^{*}$ ka:n-tè & anticipatory place assimilation \\
\hline actual: & ci:y-kè & ka:y-kè & perseverative place assimilation \\
\hline
\end{tabular}

Again, there is a $3 / 4$ situation: consonant assimilation is either anticipatory or involves the perseverative assimilation of a suffixal $C$ to a root- $C$. What is missing is the fourth possibility: assimilation of a root-C to a prefixal C.

\subsection{Consonant harmony $(\mathrm{CH})$}

Numerous languages have sibilant, lateral/rhotic, nasal and other consonant harmonies. These phenomena are studied in great detail by Hansson (2001), who explicitly states that consonant harmony is either root-controlled or anticipatory. He sums up his findings as follows: 
“..consonant harmony in heteromorphemic contexts seems to display only two fundamental directionality patterns. One is stem control, whereby affixes harmonize with the base to which they attach. This can give rise either to right-to-left harmony (in prefixation contexts) or to left-to-right harmony (in suffixation contexts), or a combination of both (i.e. 'bidirectional' harmony) in those cases where prefixes and suffixes are both within the domain in which harmony holds. The other type is fixed directionality, which is insensitive to morphological structure. In this case, harmony applies in a right-to-left fashion, i.e. as anticipatory assimilation. There are no cases of fixed directionality involving progressive (left-to-right) assimilation. Put somewhat differently, a suffix may affect the stem it attaches to, or it may be affected by that stem; a prefix, on the other hand, may be affected by the stem it attaches to, but it may not affect that stem. In other words, progressive harmony never goes against what the morphological structure dictates, but anticipatory harmony frequently does." (pp. 198-9)

The missing fourth case would be where a prefixal C causes a root (stem) consonant to harmonize.

\subsection{Vowel harmony (VH)}

In a study on directionality in vowel harmony, Hyman (in press) claims that the same $3 / 4$ asymmetry is at work here. $\mathrm{VH}$ and $\mathrm{CH}$ show the same 3/4 property, except: (i) root-control is more prevalent in $\mathrm{VH}$ than in $\mathrm{CH}$; (ii) $\mathrm{VH}$ is more likely to target a reduced segment (vowel) than $\mathrm{CH}$; (iii) $\mathrm{CH}$ may apply to underlyingly contrastive consonants (e.g. /s/ vs. / ̌s/), while (root-controlled) VH is typically nonneutralizing. Concerning directionality in VH, Hansson (2001:180) is well-aware of the complexities involved: 'If anything, progressive vowel harmony appears to be more common cross-linguistically than regressive vowel harmony, but this may well be due to the fact that suffixation is far more common than prefixation'." (See also §4.6.)

\subsection{Stress}

Stress may also be subject to root-control (Alderete 2001b) as well as a directional asymmetry. Two studies have quantified primary stress placement cross-linguistically, summarized in (14). 
(14) Left- vs. right-edge stress placement

\begin{tabular}{l|c|c|c|c||c|c|} 
& \multicolumn{1}{c}{ initial } & \multicolumn{1}{c}{ peninitial } & \multicolumn{1}{c}{ penultimate } & \multicolumn{1}{c}{ final } & \multicolumn{1}{c}{ left-edge } & right-edge \\
\cline { 2 - 7 } \\
Hyman 1977 & 114 & 12 & 77 & 97 & 116 & 174 \\
\cline { 2 - 7 } & 11 & 2 & 9 & 4 & 13 & 13 \\
\cline { 2 - 7 }
\end{tabular}

While Hyman (1977) surveyed many more languages, some of the systems converge in their stress patterns due to genetic or areal factors (e.g. the number of Turkic languages included bias the results towards right-edge final stress assignment). Bybee et al's (1998) language sample is much smaller, but explicitly designed to avoid similiarities which may be due to a common history. As seen, both studies show that stress placement is readily calculated from either the left- or the right edge of the relevant domain. There is, however, an asymmetry: At the left edge, cases of initial stress vastly outnumber cases of second syllable stress; at the right edge, both final and penultimate stress are attested.

As mentioned, the 1977 sample was not controlled, and it is therefore possible that final stress languages are overrepresented, i.e. that penultimate position may actually be favored over final. Although my notes are not always explicit (either my fault or due to the original source), I recalculated stress placement in those languages where I had indicated the domain (stem, word, phrase). The results are presented in (15).

(15) Stress placement by domain (based on Hyman 1977)

\begin{tabular}{l|c|c|c|c|c|}
\multicolumn{1}{c}{ initial } & \multicolumn{1}{c}{ peninitial } & penultimate & final & \multicolumn{1}{c}{ totals } \\
Stem & 15 & 0 & 1 & 4 & 20 \\
Word & 27 & 9 & 37 & 21 & 94 \\
Phrase & 5 & 0 & 2 & 2 & 9 \\
totals & 47 & 9 & 40 & 27 & 123
\end{tabular}

The following observations are of interest. First, in this subset of languages for which my notes indicate a domain, penultimate outnumbers final stress overall (as in Bybee et al 1998). However, there are four occurrences of stem-final stress vs. only one stem-penultimate. Although the numbers are small, it would appear that stem stress is most likely than word stress to be edge-adjacent, with a distinct preference for stem-initial. While nine cases of word-peninitial stress can be identified, stem-peninitial stress is unattested in the sample.

The above numbers do not differentiate between languages which are reported to have simple initial/final stress vs. those whose secondary stresses indicate the construction of stress feet. Hayes (1995) presents a detailed account of such systems and their variations. Stress feet can be constructed 
left-to-right or right-to-left. However, Hayes (1995:265) concludes that "the evidence to decide the issue of right-to-left iambs conclusively appears to be lacking." See also Bye \& De Lacy (2000) who cite metrical evidence in favor of their Edge-Asymmetry Hypothesis: "No constraint may refer to the right edge of a constituent" (p.122).

Finally, another indication of a right-left asymmetry in stress systems is that "dominant" affixes, which have been discussed by Inkelas $(1996,1998)$, Alderete $(2001 a, b)$, and others, are much more likely to be suffixes than prefixes.

\subsection{Dissimilation}

There also is evidence that dissimilation is generally anticipatory or root-controlled, hence subject to the same $3 / 4$ situation. This is, however, harder to show, given the wide range of dissimilatory processes that are frequently grouped together (see Suzuki 1998). One case comes from Dahl's Law, which characterizes a number of Eastern Bantu languages (Meinhof \& van Warmelo 1932). The following representative Kirundi examples are from Meeussen (1959:42):

(16) Dahl's Law in Kirundi

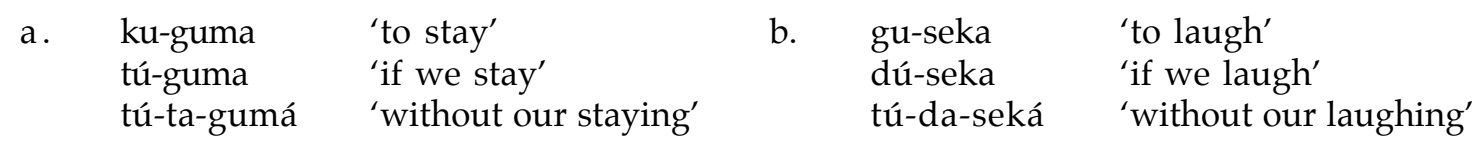

In (16a), where the root begins with the voiced obstruent $/ \mathrm{g} /$, the underlying prefixes $/ \mathrm{ku}-/$, / tú-/, and /-ta-/ are realized unchanged, hence *dú-ta-gumá. In (16b), however, where the root begins with the voiceless obstruent /s/, these prefixes undergo voicing dissimilation to gu-, dú- and -da-, respectively. Although Davy \& Nurse (1982) document a number of languages where dissimilation applies iteratively, only the root-adjacent prefix -ta- 'negative' dissimilates in the third example in (16b), i.e. we do not obtain *dú-da-seká. The involvement of the root is seen in the last example in (16a), where the prefix -ta- 'negative' fails to trigger dissimilation on the consonant of the preceding prefix tú- '1 $1 \mathrm{pl}^{\prime}$, i.e. we do not obtain *dú-ta-gumá. However, Dahl's Law is not only root-controlled in Kirundi, as seen from the following verb forms: -bád-ik- 'transplant', -bád-uk- 'grow well' vs. -bát-ur- 'uproot (plants) to transplant them'. Here we see that the frozen suffixes -ik- and -uk- condition voicing of the underlyingly voiceless root-final consonant $/ t /$, which does surface in the last form. Dahl's Law thus operates either between a root and an adjacent prefix, or is anticipatory within the stem domain. 


\subsection{Further discussion}

The following summarizes what has been said up to this point:

(17) a. When a process is root-controlled, either prefixes or suffixes may be affected.

b. There is an anticipatory bias which should:

(i) make prefixes better targets for reduction, fusion, and loss than suffixes

(ii) make suffixes better triggers for harmony and other phonological processes.

The implication of the above is that when segments interact across identical constituent types (wordword, stem-stem, root-root, affix-affix), the effect should be anticipatory.

To test such claims, a full discussion of directional possibilities must include cases of multiple prefixation and suffixation, as in (18).

$$
\text { [P1 - P2 - R - S1 - S2 ] word }
$$

Using this schema, where $\mathrm{P}=$ prefix, $\mathrm{R}=$ root, and $\mathrm{S}=$ suffix, and based on what has been reported in the literature, Hyman (in press) judges vowel harmony possibilities as in (19).

(19) VH target/trigger + directional possibilities of forms with two prefixes and/or suffixes

left to right right to left left to right right to left

a. local $\mathrm{VH}$

\begin{tabular}{|c|c|c|c|c|c|}
\hline P1 & $\rightarrow \quad \mathrm{P} 2$ & $?$ & P2 & & P1 \\
\hline 2 & $\rightarrow \mathrm{R}$ & $?$ & $\mathrm{R}$ & $\rightarrow$ & P2 \\
\hline 2 & $\rightarrow \mathrm{S} 1$ & $\checkmark$ & S1 & $\rightarrow$ & $\mathrm{R}$ \\
\hline & $\rightarrow \mathrm{S} 2$ & $?$ & $\mathrm{~S} 2$ & $\rightarrow$ & S1 \\
\hline
\end{tabular}

b. non-local $\mathrm{VH}$ (affix transparency) $\mathrm{P} 1 \quad \rightarrow \mathrm{R} \quad ? \quad \mathrm{R} \quad \rightarrow \mathrm{P} 1 \quad \checkmark$ $\mathrm{R} \rightarrow \mathrm{S} 2 \quad J \quad \mathrm{~S} 2 \rightarrow \mathrm{R} \quad J$

c. non-local $\mathrm{VH}$ (root transparency) $\mathrm{P} 2 \quad \rightarrow \mathrm{S} 1 \quad$ ? $\quad \mathrm{S} 1 \rightarrow \mathrm{P} 2 \quad$ ? d. non-local $\mathrm{VH}$ (affix+root transparency)

$$
\begin{aligned}
& \mathrm{P} 1 \rightarrow \mathrm{S} 1 ? \text { ? } \quad \mathrm{S} 1 \rightarrow \mathrm{P} 1 ? \\
& \mathrm{P} 1 \rightarrow \mathrm{S} 2 ? \quad \mathrm{~S} 2 \rightarrow \mathrm{P} 1 ? \\
& \mathrm{P} 2 \rightarrow \mathrm{S} 2 \text { ? } \quad \mathrm{S} 2 \rightarrow \mathrm{P} 2 \text { ? }
\end{aligned}
$$

e. root-root compound $\mathrm{VH}$

$$
\mathrm{R} 1 \quad \rightarrow \quad \mathrm{R} 2 \checkmark \quad \mathrm{R} 2 \rightarrow \mathrm{R} 1 \checkmark
$$

f. root-internal VH (also within P \& S)

$$
[\mathrm{V} \rightarrow \mathrm{V}]_{\mathrm{R}} \quad[\mathrm{V} \leftarrow \mathrm{V}]_{\mathrm{R}}
$$

Widely attested processes are marked by $(/)$ and include anticipatory and root-control harmony. On the other hand, a number of recent works have noted the (near-) absence of prefix-controlled vowel harmony, marked by (?). However, the (?) on P1 $\rightarrow$ P2 indicates that we need to ask whether this is because of a condition on prefixes as triggers, roots as targets, or both. Specifically, can a prefix initiate vowel harmony onto prefixes to its right or left? If the parameters are root-control and anticipatory assimilation, then the checks vs. question marks in (19a) indicate the following: (i) P2 can harmonize 
P1, but P1 cannot harmonize P2 (or R); (ii) S2 can harmonize S1, and S1 can harmonize R, but S1 cannot harmonize S2. ${ }^{8}$ All of these claims need to be tested against another dichotomy, stem vs. word, discussed in the next section.

\section{Stem and word domains}

The preceding sections have established that there is reason to believe in the left-right asymmetries concerning prefixing vs. suffixing and anticipatory vs. perservative phonology. However, there is a complicating factor that needs to be brought into the equation: Suffixes tend to be more tightly bound to their root than prefixes. What this means is that more languages have the structure in (20a) than in (20b).

(20) Suffixes tend to be more tightly bound to their root than prefixes

a.

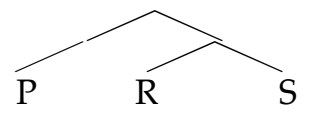

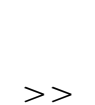

b.

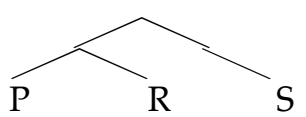

In support of this observation one might cite the proposals one finds in the literature that some or all prefixes are phonological words, e.g. in Germanic, whereas suffixes are not (Booij \& Rubach 1984, Nespor \& Vogel 1986, Wennerstrom 1993, Raffelsiefen 1999 etc.). This in turn is related to the finding of Bybee, Pagliucca \& Perkins (1991:16) that even beyond affixes, preposed grammaticized elements tend in to be less bound than postposed. Languages do exist which have either multiple prefixation + one suffix slot or multiple suffixation + one prefix slot, suggesting both structures in (20). However, those which have both multiple prefixation and multiple suffixation appear almost always to have the structure in (20a). ${ }^{9}$ The structure in (20a) is also consistent with the observation that suffixes are more prone to reduction than prefixes, just as post-tonic elements are more prone to reduction than pre-tonic elements (cf. Barnes 2002 and references cited therein). This, however, leads to the conclusion that some forces conspire against prefixes and others against suffixes. Recall Greenberg's (1957) distinction between "origin" and "survival" in §2.2. Whereas Greenberg hypothesized that prefixes are vulnerable targets of anticipatory assimilation-and hence less likely to survive, Bybee, Pagliucca \& Perkins (1991) hypothesize that prefixes are less likely to develop in the first place. ${ }^{10}$ Although Greenberg hypothesized that suffixes are more secure, we see them as more tightly bound, subject to reduction and ultimate assimilation or loss. How can these contradictory views be reconciled? 
It should be evident from the above that many of the expressed views, including my own, are impressionistic, based on our personal experience or intuitions. An exception is Bybee, Pagliucca \& Perkins (1991), who test various claims concerning asymmetries in affixation against a sample of 71 languages which have been carefully selected to minimize genetic or areal convergences. Significantly, the languages were not chosen because they were felt to provide the best inputs for studying the nature of prefixing vs. suffixing. An alternative approach would be to look in some depth at languages which are specifically selected for their rich affixation systems. Two strategies might be followed: (i) compare languages with multiple prefixation vs. languages with multiple suffixation; (ii) look at languages with multiple prefixation and multiple suffixation. This latter strategy is adopted in the following subsections which examine stem vs. word properties in the Bantu group of ca. 500 languages. The properties of stem- and word domains are treated, respectively, in §5.1 and §5.2.

\subsection{The stem domain}

Although Sapir (1921:126) characterizes Bantu as "prevailingly prefixing", data such as in (21) demonstrate that suffixes abound:

(21) Derivational suffixes ("extensions") in the Ciyao verb stem (Ngunga 2000)
a. taam-
'sit'
b. taam-ik-
'seat' (put in seated position)
-ik- (impositive)
c. taam-uk-ul-
'unseat'
d. taam-uk-ul-igw-
'be unseated'
e. taam-uk-ul-igw-aasy-
'cause to be unseated'
f. taam-uk-ul-igw-aasy-an-
'cause each other to be unseated'
g. taam-uk-ul-igw-aasy-an-il- 'cause e.o. to be unseated for/at'
-ul- (reversive tr.)
-igw- (passive)
-aasy- (causative)
-an- (reciprocal)
-il- (applicative)

The above verbs are derived verb bases which require other morphemes to form acceptable stems and words. ${ }^{11}$ We shall now see that the Bantu stem is built via suffixation, while the word is built via prefixation.

Ignoring clitics, the Proto-Bantu word structure of verbs is shown in (22).

Proto-Bantu word structure of verbs (Meeussen 1967)

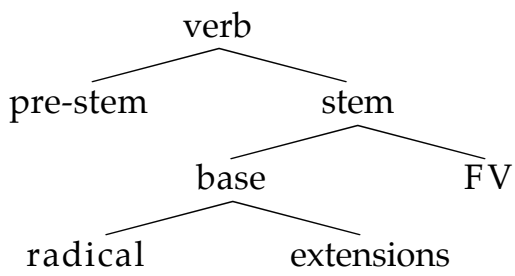


In (23), the different subconstituents and their canonical and non-canonical shapes are identified:

(23) Identification of subconstituents and their canonical and non-canonical shapes

$\begin{array}{lllll} & & \text { canonical } & \text { non-canonical } \\ \text { a. } & \text { pre-stem } & \text { subj, neg, tense, asp, obj prefixes } & \mathrm{CV}- & \mathrm{V}-, \mathrm{N}-,(\mathrm{C}) \mathrm{VV}-\text { ? } \\ \text { b. } & \text { radical } & \text { verb root } & \neq \mathrm{CV}(\mathrm{N}) \mathrm{C}- & \neq \mathrm{CV}, \neq \mathrm{CVVC}-, \neq \mathrm{VC}- \\ \text { c. } & \text { extensions } & \text { expansions / derivational suffixes } & -\mathrm{VC}- & -\mathrm{V}-,-\mathrm{VNC}-,-\mathrm{C}- \\ \text { d. } & \text { FV } & \text { inflectional final suffix } & -\mathrm{V} & -\mathrm{VV},(-\mathrm{VC}-\mathrm{V})\end{array}$

There are two constituents of particular interest: The verb stem consists of a verb base (root plus derivational suffixes) and an obligatory inflectional final vowel (FV) morpheme, most commonly -a. The verb (word) consists of a stem plus inflectional prefixes (pre-stem). The column of canonical shapes show the following:

(i) prefixes are canonically C-initial, while suffixes are canonically V-initial

(ii) prefixes are canonically V-final, while (non-final) suffixes are canonically C-final

(iii) roots are canonically $-\mathrm{CV}(\mathrm{N}) \mathrm{C}$-, i.e. C-initial and C-final

If the canonical shapes are concatenated, we obtain the following schema of the canonical full verb: $(\mathrm{CV})^{*}-\mathrm{CV}(\mathrm{N}) \mathrm{C}-(\mathrm{VC})^{*}-\mathrm{V}$. Although non-canonical morpheme shapes do exist, concatenation of canonical morpheme shapes produces CV syllables. Depending on the language, the availability of multiple prefixes and suffixes can produce quite elaborate words, such as the one from Kinande in (24).

(24) Elaborate Kinande example (Ngessimo Mutaka, cited in Nurse \& Philippson 2003b:9)

tu-né-mu-ndi-syá-tá-sya-ya-ba $\neq$ king-ul-ir-an-is-ị-á =ki-ô $\quad(\neq$ stem; = clitic $)$

'we will make it possible one more time for them to open it for each other'

While (22) represents the traditional Bantuist view of Bantu verb structure, there have been several elaborations to this scheme, such as the one in (25).

(25) Elaboration of Bantu verb structure (Downing 1999:75)

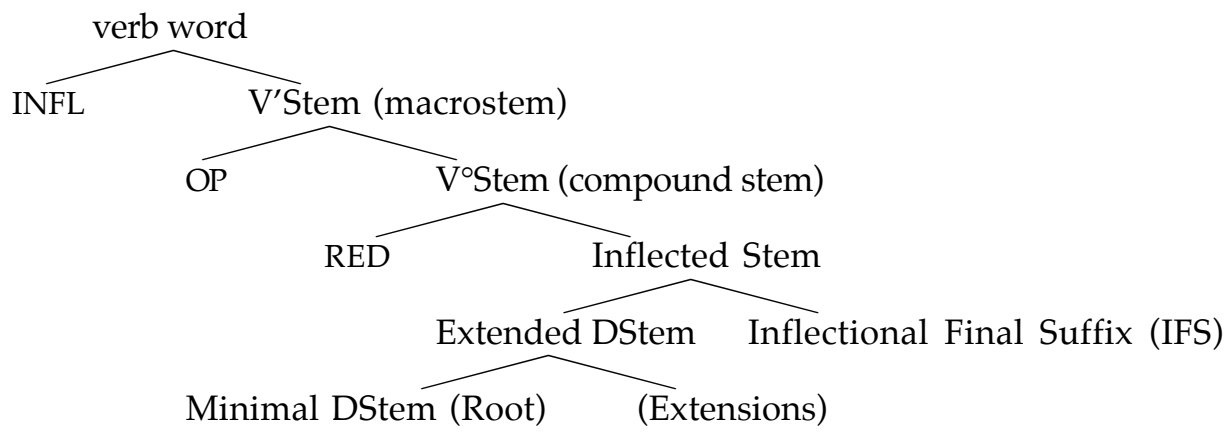


The question is how (23) or (25) translate into prosodic domains. Some of the possibilities are seen in (26).

(26) Analysis into domains ( $\mathrm{GW}=$ grammatical word; PW = phonological word)
a. Traditional
b. Myers $(1995,1998)$
c. Among other possibilities
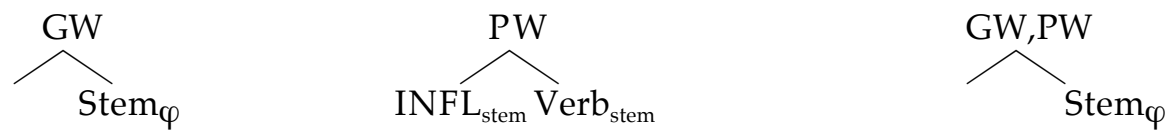

As seen, all analyses give special status to the stem, discussed in this subsection, and the word, discussed in §5.2. What is important for the present purposes is to recognize that Meeussen’s ProtoBantu stem is the unambiguous locus of much of phonological or prosodic activity in Bantu, as summarized in (27).

(27) Meeusen's Proto-Bantu stem is an unambiguous locus of prosodic activity in Bantu
a. vowels:
distribution, vowel harmony
b. consonants:
nasal consonant harmony
c. tones: distribution, Meeussen's reconstruction of extension tones
d. reduplication: verb reduplication is usually limited to the stem

In the remainder of this section, each of these stem properties will be examined in turn.

The distribution of vowels by position in Proto-Bantu is shown in (28).

PB vowel reconstructions by position (4-7-4-7)

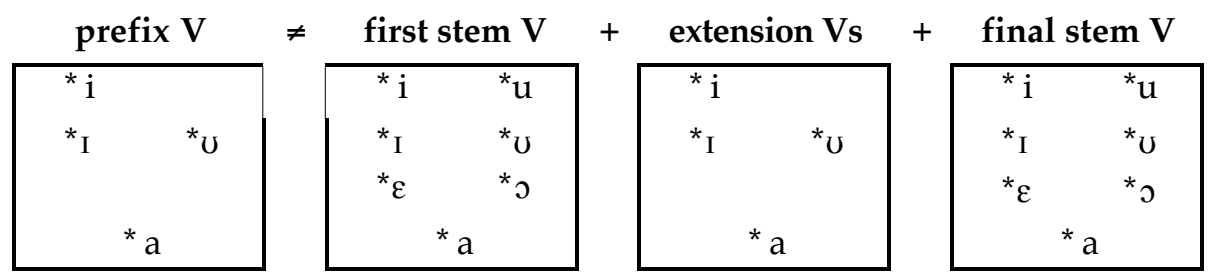

As seen, Proto-Bantu had a seven-vowel system, the full set of which we find in the first and last position of the stem. Prefix and extension vowels, however, were limited to four, with ${ }^{*} i$ being rarer than the other three. What distinguishes prefixal from post-radical extension vowels, however, is the vowel height harmony to which the latter are subjected:

(29) "Asymmetric" vowel height harmony (Hyman 1999)
a. front : ${ }^{*} \mathrm{I}>\varepsilon /\{\varepsilon, 0\} \mathrm{C}$
b. back : ${ }^{*} U>0 /\{0\} \quad \mathrm{C}$

As seen, the degree two vowel * ${ }^{*}$ becomes $[\varepsilon]$ after the two mid vowels ${ }^{*} \varepsilon$ and ${ }^{*} 0$, while * $U$ becomes [0] only after *o. Hyman (1999) documents which languages have such "asymmetric" height harmony as 
well as other variations, including certain languages which have extended the process to prefixes. Note that the FV is typically not targeted by vowel height harmony.

While vowel distribution is affected by the position within the stem and word, (30) shows a different situation with respect to Proto-Bantu consonant distribution:

(30) Distribution of consonants by position

\begin{tabular}{|c|c|c|c|c|c|c|c|c|c|c|c|c|c|c|c|c|}
\hline & ${ }^{*} p$ & ${ }^{*} \mathbf{t}$ & ${ }^{*} \mathrm{c}$ & ${ }^{*} \mathbf{k}$ & ${ }^{*} \mathbf{b}$ & ${ }^{*} \mathrm{~d}$ & ${ }^{*} \mathbf{j}$ & ${ }^{*} \mathbf{g}$ & ${ }^{*} \mathbf{m}$ & ${ }^{*} \mathbf{n}$ & ${ }^{*} \mathrm{n}$ & ${ }^{*} \mathbf{m b}$ & ${ }^{*}$ nd & *nj & ${ }^{*}$ yg & totals \\
\hline pref & 2 & 5 & & 9 & 5 & 2 & 4 & 3 & 8 & & & & & & 1 & 39 \\
\hline$C_{1}$ & 222 & 281 & 181 & 300 & 205 & 253 & 207 & 172 & 43 & 35 & 11 & & & & 3 & 1913 \\
\hline $\mathrm{C}_{2}$ & 71 & 116 & 40 & 180 & 93 & 360 & 50 & 80 & 126 & 100 & 12 & 173 & 119 & 31 & 213 & 1764 \\
\hline $\mathrm{C}_{3}$ & 1 & 22 & 4 & 54 & 10 & 124 & 1 & 5 & 34 & 15 & 1 & & & & 9 & 280 \\
\hline suff & 1 & 2 & 1 & 3 & 1 & 5 & & & 1 & 1 & & & & & 1 & 16 \\
\hline
\end{tabular}

The numbers in (30) are based on 1939 lexical records in Meeussen (1969) plus the grammatical morphemes reconstructed by Meeussen (1967). The $C_{1}, C_{2}$ and $C_{3}$ designate positions in roots with up to three consonants, i.e. $\mathrm{C}_{1} \mathrm{VC}_{2} \mathrm{CV}_{3}$. As indicated by the shaded cells, the major restriction that stands out concerns nasal clusters, which, except for ${ }^{*} \mathrm{yg}$, occur exclusively in $C_{2}$ position (cf. Teil-Dautrey 2004). ${ }^{12}$ Although most analyses of present-day Bantu languages propose that the syllable break appears before a nasal cluster, Downing (2005) argues that the preconsonantal nasal is syllabified as a coda. If correct, this would allow us to hypothesize that nasal clusters were restricted to $C_{2}$ position because only the initial stem syllable could have a coda in Proto-Bantu (cf. Basaa in (38a)).

Although not a property of Proto-Bantu, there is a common nasal harmony process that affects only post-radical voiced stem consonants. Yaka examples are seen in (31).

(31) Innovative (long-distance) nasal consonant harmony in Yaka (Hyman 1995)
a. kík-idi 'block+perf'
kúd-idi 'chase+perf'
kás-idi 'tie+perf'
b. kún-ini 'plant+perf'
mák-ini 'climb+perf'
mítuk-ini 'pout+perf'

Prefixes never trigger (or undergo) the perseverative nasal harmony process, which also will never target $C_{1}$ consonants. Thus, even innovative processes show a sensitivity to the stem domain in the daughter languages.

Besides vowel and consonant properties, the stem is an important locus of tonal phonology. As seen in (32), two tones are reconstructed in Proto-Bantu: ${ }^{13}$ 
(32) Tonal distributions in the Proto-Bantu word

\begin{tabular}{|c|c|c|}
\multicolumn{1}{c|}{ prefix Vs } & $\neq$ first stem $\mathbf{V}+$ extension Vs $+{ }^{*} \mathrm{H},{ }^{*} \mathrm{~L}$ \\
${ }^{*} \mathrm{H},{ }^{*} \mathrm{~L}$ & ${ }^{*} \mathrm{H},{ }^{*} \mathrm{~L}$ \\
\hline
\end{tabular}

As in the case of vowels, it is the post-radical extension vowels which fail to provide the full contrast. As shown in (33), Meeussen $(1961,1967)$ proposes a rule of anticipatory tonal assimilation of * $\mathrm{H}$ or ${ }^{*} \mathrm{~L}$ of FV onto extension vowels in Proto-Bantu:

(33) Anticipatory tonal assimilation from the final onto extension vowels (Meeussen 1961, 1967)

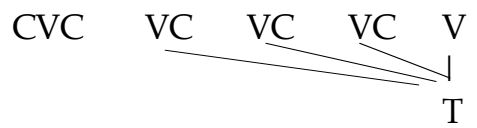

Whereas the above tonal assimilation is anticipatory, we saw in (29) that vowel harmony is perseverative (root-controlled). Some Bantu languages in the Western and Northwestern part of the zone have innovated anticipatory vowel harmony as well. Thus, (34) summarizes the realization of post-radical vowel combinations in Punu:

(34) Innovative anticipatory vowel harmony of post-radical vowels in Punu (Fontaney 1980)

$\mathrm{CVC}+$

\begin{tabular}{|c|c|c|c|c|}
\hline \multirow[b]{2}{*}{ iC } & $\mathbf{i}$ & $\mathbf{u}$ & $\mathbf{a}$ & \multirow[b]{2}{*}{$\mathrm{Cu}$} \\
\hline & $\mathrm{iC}-\mathrm{i}$ & $\underline{\mathrm{u} C}-\mathrm{u}$ & $\mathrm{iC}-2$ & \\
\hline $\mathbf{u C}$ & $\mathrm{uC}-\mathrm{i}$ & $\mathrm{uC}-\mathrm{u}$ & $\mathrm{uC}-2$ & \\
\hline C & $\underline{\mathrm{i} C}-\mathrm{i}$ & $\underline{\mathrm{uC}}-\mathrm{u}$ & $\partial \mathrm{C}-\partial$ & $\mathrm{a} \rightarrow \mathrm{u} / \ldots \mathrm{Cu}$ \\
\hline
\end{tabular}

As seen, both suffixal / $\mathrm{i} /$ and /a/ assimilate to a following / $\mathrm{u}$ /, while suffixal / a/ also assimilates to a following /i/. Vowel harmony never affects the root vowel or prefixes. In addition, non-assimilated suffixal /a/'s are realized [ə], while both root and prefixal /a/'s are realized [a]. Like the tonal process in (33), the inescapable conclusion here is that suffix vowels assimilate in a right-to-left fashion.

Recall that the four reconstructed extension vowels in (28) occur between a full set of seven vowels in Proto-Bantu and many daughter languages. The toneless extensions are also surrounded by the root and FV, both of which display a * $\mathrm{H}$ vs. ${ }^{*} \mathrm{~L}$ tonal contrast. To account for the limited distinctiveness and weakness of the extensions, which are targeted both by vowel harmony and tone spreading, Hyman (1998) proposes that the extension domain constitutes a "prosodic trough" $\tau$. This corresponds to the observation in (4b) above, whereby initials are most prominent, followed by finals, followed by middles. 
In much of what I shall refer to as Central Bantu (CB), derived verb stems can be quite long (cf. Ciyao in (21)). In contrast, Punu and many Northwest Bantu (NWB) languages are subject to stemmaximality conditions. As summarized in (35),

(35) Four-syllable maximum stem in Punu (Blanchon 1995)
a. Attested
b. Not attested
[total $=1724$ verbs $]$
CVC-iCiC-V : 24
CVC-uCuC-V : 61
${ }^{*} \mathrm{CVC}-\mathrm{iCuC}-\mathrm{V}$
CVC-aCaC-V : 69
${ }^{*} \mathrm{CVC}-\mathrm{iCaC}-\mathrm{V}$
CVC-uCiC-V : 16
(CVC-uCaC-V) : 4
${ }^{*} \mathrm{CVC}-\mathrm{aCuC}-\mathrm{V}$
$(\mathrm{CVC}-\mathrm{aCiC}-\mathrm{V}): 2$

stems in Punu are maximally quadrisyllabic with severe constraints on vowel (and consonant) distributions within the prosodic trough (cf. (34)). A similar situation is found also in Yaka (Hyman 1998, based on Ruttenberg 1971 [2000]).

Other NWB languages limit the stem to a maximum of three syllables, e.g. Koyo:

(36) Three-syllable maximum stem in Koyo
a. kór-a 'to tie'
kór-is-a 'to cause to tie'
kór-in-a 'to tie each other'
*kór-is-in-a, "kór-in-is-a
b. dzáa 'to eat' /dzé-a/
dzé-s-a 'to cause to eat, feed'
dzé-n-a 'to eat each other'
dzé-s-en-a 'to feed each other'
bar-a 'to bite'
bar-is-a 'to cause to bite'
bar-in-a 'to bite each other'
*bar-is-in-a, *bar-in-is-a
c. yigin-a 'to get accustomed to' (" ${ }^{*}$ ig-)
yig-is-a 'to cause to be accustomed'
tá-a 'to see'
tá-s-a 'to cause to see, show'
tá-n-a 'to see each other'
tá-s-an-a 'to show each other'
súndzin-a 'to decrease, shorten' ("súndz-)
súndz-is-a 'to cause to decrease'

As seen in (36a), the verbs kór- 'tie' and bar- 'bite' can take either a causative -is- or reciprocal -inextension. What they cannot do is combine the two in either order, because forms such as *kór-is-in-a or *kór-in-is-a would surpass the trisyllabic limit on stems. We see in (36b) that CV verbs such as dzé'eat' and tá- see' can combine the two extensions, since there is room in the trisyllabic template. Finally, (36c) shows that some verbs have replacive causative suffixation: the frozen expansion [in] is replaced by -is-. What this means is that suffixation is possible only if there is room in the maximally trisyllabic stem. ${ }^{14}$

There actually are two differences between Koyo and CB. First, unlike Ciyao in (21), there is a limit to how many suffixes can be added within the stem. Second, unlike the situation in Proto-Bantu 
(30), there are severe restrictions on which underlying consonants can appear in which stem positions, as well as on their realization. The properties of the Koyo prosodic stem are summarized in (37).

(37) Properties of the prosodic stem in Koyo

a. stem structures: CV, CV.V, CV.CV, CV.CV.CV

$\begin{array}{lllllllllllllllllllll}\text { b. } & \mathrm{C}_{1}: & \mathrm{p} & \mathrm{b} & \mathrm{w} & \mathrm{m} & \mathrm{mb} & \mathrm{t} & \mathrm{l} & \mathrm{s} & \mathrm{n} & \mathrm{nd} & \mathrm{ts} & \mathrm{dz} & \mathrm{y} & \mathrm{n} & \mathrm{ndz} & \mathrm{k} & \mathrm{h} & \mathrm{gg} \\ \mathrm{C}_{2}: & & \mathrm{b} & & \mathrm{m} & \mathrm{mb} & \mathrm{r} & \mathrm{l} & \mathrm{s} & \mathrm{n} & \mathrm{nd} & & & \mathrm{y} & \mathrm{n} & \mathrm{ndz} & \mathrm{g} & \\ \mathrm{C}_{3}: & & & & \mathrm{m} & & \mathrm{r} & \mathrm{l} & \mathrm{s} & \mathrm{n} & & & & & & & & \mathrm{g}\end{array}$

The acceptable stem structures are given in (37a). These allow for up to three consonants $\left(C_{1}, C_{2}, C_{3}\right)$. As seen in (37b), the full set of consonants appears in $C_{1}$ position, while only a subset occur as $C_{2}$, even fewer as $C_{3}$. In addition, $C_{2}$ and $C_{3} / t /$ and / $/$ are realized as $[r]$ and $[\mathrm{g}]: / \mathrm{i}$-tots / $\rightarrow \mathrm{i}$-tors 'banana', /otokiti / $\rightarrow$ o-togiri 'sweat', etc. Since / p/ cannot occur in these positions, what this means is that /s/ is the only [-voice] consonant to appear non-stem-initially.

The consonant distribution and realizations in (37) point to an important edge-asymmetry in the stem phonology of NWB languages. There is a marked decrease in the number of consonantal oppositions as one goes from left to right within the stem. In addition, consonants occurring later are subject to weaker realizations. Stem-initial resistance to weakening is particularly striking in Basaa, whose stem properties are summarized in (38).

(38) Maximum of three syllable stem in Basaa

a. stem structures: CV, CVC, CV.CV, CV.CVC, CVC.CV, CVC.CVC, CVC.CV.CV

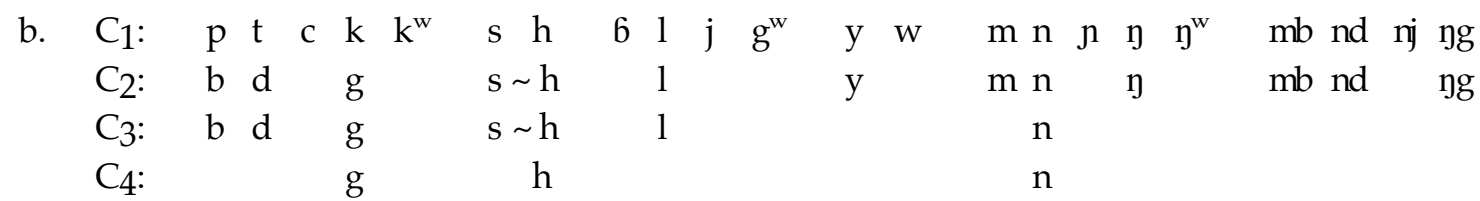

As in Koyo, Basaa stems are limited to three syllables (see Hyman $2003 \mathrm{~b} \&$ references cited therein). The full set of consonants is found in $C_{1}$ position, with progressively fewer in $C_{2}, C_{3}$ and $C_{4}$ positions. The most striking property concerns the distribution of non-contrastive voicing on stops: There is a single series of stops $/ \mathrm{P}, \mathrm{T}, \mathrm{K} /$ which is realized $[\mathrm{p}, \mathrm{t}, \mathrm{k}]$ stem-initially, but as voiced (and often continuant) in all other positions. ${ }^{15}$ Illustrations are provided in (39). 
(39) Realizations of the single stop series / P, T, K/

$\begin{array}{llll}\text { Underlying } & \text { Orthographic } & \text { Phonetic } & \\ \text { / TíTKí/ } & \text { tídgí } & \text { tírgí } & \text { 'small' } \\ \text { /KòKnà/ } & \text { kògnà } & \text { kòynà } & \text { 'crush each other' } \\ \text { /lì-màPKà/ } & \text { lìmàbgà } & \text { lì-màßgà } & \text { 'taking form' (class 5) } \\ \text { / Pì-Pà/ } & \text { bìpà } & \text { bì-pà } & \text { 'machete' (class 8) } \\ \text { / Tì-KóTá/ } & \text { dìkódá } & \text { di-kórá } & \text { 'pipes' (class 13) }\end{array}$

The voiced realizations are found not only in $\mathrm{C}_{2}, \mathrm{C}_{3}$ and $\mathrm{C}_{4}$ stem positions, but also in prefixes, e.g. class 8 / Pì-/ is realized bi- $(\sim[\beta \grave{1}-])$, and class 13 / Tì-/ and first person plural /Tì-/ are both realized dì- $(\sim$ [rì-]). As seen in (40), the continuant allophones can be conditioned by a preceding stem:

(40) Postvocalic spirantization of a prefix consonant can be conditioned by the preceding stem a. / sáá Pì-Pà/ $\rightarrow$ sáá bì-pà [sáá ßí-pà] 'scatter machetes' b. / /sáá Tì-KóTá/ $\rightarrow$ sáá dì-kódá [sáá rí-kórá] 'scatter pipes'

When class 13 / Tì-/ fuses with a vowel-initial root, thereby becoming stem-initial, the result is voiceless: / Tì-áy / $\rightarrow$ [tJăy] ‘leaves' (cf. / Tì-nùní/ $\rightarrow$ dì-nùní 'birds'). ${ }^{16}$

The importance of Basaa is that the voiceless (=strong) stop realizations are conditioned specifically by stem-initial, not word-initial position. In other cases it is hard to tell, since many of the languages which place initial strength conditions on consonants do not have prefixes (cf. the discussions in Beckman 1998 and Smith 2002). If the voicing of stops were dependent on word initiality, we would expect prefixes to alternate as well: / Pì-/ and / Tì-/ would be realized [pì-] and [tì] if word-initial, but as [bì- ßì-] and [dì- rì-] when preceded by another prefix. Since no such case has been reported, I assume that such processes specifically target the left edge of stems (cf. Smith's MWord) and propose the following asymmetry in (41).

(41) Strength asymmetry

$\begin{array}{llll}\text { a. Strong } & \text { vs. } & \text { b. } & \text { Weak } \\ \text { stem-initial } & & & \text { word-final }\end{array}$

As indicated, from the point of view of their edges, stems and words don't work the same way. While this can be partially attributed to the function of demarcating the beginning of lexical morphemes, this tendency is partly undermined by cases where a prefix fuses onto a vowel-initial root, as in Basaa / Tìáy / $\rightarrow$ [ţăy] 'leaves'. 
Paulian (1975) has interpreted similar facts as evidence of a stem-initial accent in Kukuya, another NWB language. The prosodic stem in Kukuya has the properties in (42).

(42) Properties of the prosodic stem in Kukuya (Paulian 1975; cf. Hyman 1987)
a. Five syllable shapes:
CV, CV.V, CV.CV, CVV.CV, CV.CV.CV
b. Five tonal "melodies":
L, H, LH, HL, LHL
c. Six $\mathrm{C}_{2}$ or $\mathrm{C}_{3}$ possibilities:
$\mathrm{P}, \mathrm{T}, \mathrm{K}, \mathrm{l}, \mathrm{m}, \mathrm{n}$
d. Six $\mathrm{C}_{2}-\mathrm{C}_{3}$ combinations:
C-n-m, C-T-K, C-1-K, C-1-P, C-K-P, C-T-P
e. Prefix consonants:
$\mathrm{P}, \mathrm{K}, \mathrm{l}, \mathrm{m}$

As seen in (42a), stems may have from one to three syllables and be mono-, bi- or trimoraic. Independent of their length, Paulian identifies exactly the five "schèmes tonals" (tonal melodies) in (42b). While the language contrasts a large number of stem-initial consonants (some with complex secondary articulations), only the six in (42c) occur in $C_{2}$ or $C_{3}$ positions: Among these are the underspecified consonants $/ \mathrm{P} /, / \mathrm{T} /$, and $/ \mathrm{K} /$, which are realized, respectively, as $[\mathrm{b} \sim \beta],[\mathrm{r}]$, and $[\mathrm{k} \sim \mathrm{g} \sim \mathrm{\gamma}]$. Since six consonants are possible, we expect 36 (i.e. $6 \times 6$ ) possible combinations of $C_{2}+C_{3}$. However, as indicated in (58d), there are only six combinations. Missing are cases where the $C_{2}$ and $C_{3}$ consonants are produced at the same place of articulation or where they disagree in nasality. In addition, the attested sequences must be either coronal $C_{2}+$ non-coronal $C_{3}$ or velar $C_{2}+$ labial $C_{3}$. Finally, as indicated in (42e), prefix consonants are restricted to only four: / $\mathrm{P}, \mathrm{K}, \mathrm{l}, \mathrm{m} /$.

As presented, the Kukuya facts are an elaboration of what has been seen in Koyo and Basaa. ${ }^{17}$ Even more important are three additional properties pointed out by Paulian (1975):

(i) there is a "pause", however slight, before every $\mathrm{C}_{1}$ consonant

(ii) a $C_{1}$ nasal or $/ 1 /$ is automatically geminated (/Pù $\neq$ nónó/ $\rightarrow$ [bù.nnó.nó] 'selfishness')

(iii) prefixes join the preceding stem to form a clitic-group-like P-domain

Paulian takes all of the above properties—especially (i) and (ii)—to be indications of a stem-initial accent in Kukuya. The most striking fact is perhaps that in (iii): Prefixes which do not fuse with a vowel-initial root instead join a preceding stem to form a clitic-group-like prosodic domain (Hyman 1987). One possible interpretation is "ex-prefixation": prefixes break off and join a preceding stem to form a domain. Another is that these noun class markers, inflectional markeres on verbs etc. are not prefixes at all, rather proclitics. Either way the generalization is that P-domains are stem-initial in Kukuya. Adopting proposals of Chen (1987) and Selkirk (1986), an end-based algorithm of the sort 
"mark off the beginning of every stem" would work quite well in Kukuya, leaving only an utteranceinitial prefix/proclitic as extraprosodic. The important issue is that there is no phonological interaction between what otherwise appear to be prefixes and their respective stems.

Before moving on to consider word domains, for completeness, let us briefly mention the rather well-known phenomenon of verb stem reduplication in Bantu. In both NWB and CB verb reduplication typically excludes prefixes. The exceptions concern cases where the inclusion of one prefix either provides a needed second syllable (in case the stem is monosyllabic), or provides an onset to the reduplicant (see Downing 1999 and references cited therein). Other Bantu languages consistently exclude prefixal material in all cases.

To summarize, the Bantu verb stem is clearly the locus of considerable phonological activity subject to clear left-right asymmetries. Since prefixes are excluded, one interpretation has been that stem-level processes constitute the "stratum 1" phonology of lexical phonology (Kiparsky 1982, 2000). ${ }^{18}$ Stratum 2 or post-lexical word domains, which include prefixes if not also clitics, are the subject of the next section.

\subsection{Word domains}

In the preceding section we saw that the stem functions as a prosodic domain in most, if not all Bantu languages. Let us refer to this as the P-stem, whose left edge is normally marked by the root. We have been able to define the P-stem because several criteria converge (C/V distributions, vowel harmony, consonant harmony, tone, etc.). In this section we address a more difficult issue, that of defining the word domain (or domains) in Bantu. As we shall see, the traditional Bantuist definition of the word (prefixes + stem) works in some cases, but not others.

I begin by providing in (43) a list of arguments that would together confirm the validity of the phonological word (PW) as a distinct domain from the grammatical word (GW) (cf. Selkirk 1980, 1984; Nespor \& Vogel 1986, etc.):

(43) Potential arguments distinguishing PW from GW

a. multiple reference to the same PW

b. different types of reference (e.g. left-/ right-edge of PW, throughout the PW etc.)

c. higher (PhP) and lower (foot) reference to the same PW within a prosodic hierarchy

d. no contradictory reference (e.g. a part of one PW cannot belong to another PW) 
e. cross-linguistic comparability (i.e. PW is well-defined across languages)

It is often said that the PW is non-isomorphic with the GW. Linguists have described at least three situations where PW $\neq$ GW (cf. Booij 1983, Nespor \& Vogel 1986):

(44) Three situations where $\mathrm{PW} \neq \mathrm{GW}$
a. $\mathrm{PW}<\mathrm{GW}$ : $\mathrm{PW}$ is foot-like
b. $\quad P W>G W$ : $P W$ is CG-like
c. $\quad \mathrm{PW}<>\mathrm{GW}$ : $\mathrm{PW}$ is compound-like

The first situation (44a) is where the PW is smaller than the GW, i.e. it is foot-like. Those analyses which propose that prefixes are PWs in Germanic, or where maximally bisyllabic reduplicants are PWs in Bantu are examples. The second situation (44b) is where the PW is larger than the GW. In this case the PW consists of the GW augmented by proclitics and/or enclitics, thus resembling the clitic group (CG) domain (Nespor \& Vogel 1986). This notion of PW has been proposed for certain Bantu languages, e.g. Shona: "A phonological word... consists of a full word with a maximal string of functional words cliticized onto one end. Phonological words in different languages differ in just two parameters: the membership of the set of functional categories, and the direction of cliticization" (Myers 1995:85). Finally, (44c) is intended to describe compounds where prefixes form a domain with the first stem and suffixes a domain with the second stem: prefix-stem 1 部em 2 -suffix.

It is not clear whether the above characterizations are contradictory or complementary. It may in fact be necessary to distinguish different kinds of PW, which may or may not coincide in a given language. Some of the possibilities are listed in (45).

(45) Different kinds of PW?
a. the demarcative word
b. the culminative word
c. the harmonic word
d. the metrical word
e. the minimal word
f. the maximal word
g. the phonotactic word
a property marks the beginning or end of the word a feature occurs only once per word
a feature is realized throughout the word a word consists of hierarchically arrayed moras or syllables a word must consist of a minimum \# of moras or syllables a word can consist of a maximum \# of moras or syllables
$h$. the morphophonotactic word a word permits only certain output segments/sequences a word permits only certain input segments/sequences

Even within the above categories, we must confirm that different phonological features define the same PW (VH, tone, nasalization, etc.). Within Bantu this is easier to do with respect to the P-stem than the PW. 
To anticipate the following discussion, three major points can be made concerning "small and large" word-like P-domains in Bantu:

(i) Bantu languages seem alike but mask a lot of differences

(ii) When a language has enough going on in its P-domains, there can be "mismatches", syntactic conditions, and "look ahead" phenomena (e.g. Hayes 1987).

(iii) Much of Northwest Bantu is quite different from the rest of Bantu.

Consider, first, the relevance of Meeussen's Rule (MR) in establishing PWs. This is a rule of high tone dissimilation by which a $/ \mathrm{H}+\mathrm{H} /$ input is realized $\mathrm{H}-\mathrm{L}$ (or $\mathrm{H}-\varnothing$ ). Myers (1998) analyzes MR as applying only across a macrostem or clitic boundary in Shona: ${ }^{19}$

(46) Meeussen's Rule said to apply only across a macrostem or clitic boundary in Shona
a. [ndi-cha-] [ tenga ]
'I will buy'
(cf. ku-téngá 'to buy')

$\begin{array}{ll}\mathrm{H} & \underline{\mathrm{H}}\end{array}$

b. [ va-cha-] [ tenga ] $\rightarrow$ vá-chá-tenga 'they will buy'

$\begin{array}{lllll}\text { I } & \text { I } & \text { V } & \text { । } & \text { । } \\ \mathrm{H} & \mathrm{H} & \mathrm{H} & \mathrm{H} & \mathrm{H}\end{array}$

c. [ku $][$ ri-tenga $] \rightarrow$ ku-rí-téngá 'to buy it' (the class 5 object marker ri-

I $\quad$ ।

$\mathrm{H} \quad \mathrm{H} \quad \mathrm{H} \quad \underline{\mathrm{H}}$

d. [ne] [ banga

$\mathrm{H} \quad \underline{\mathrm{H}}$

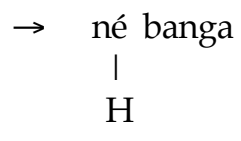
'with a knife'
(proclitic + noun) belongs to the "macrostem")

e. [mwana ] [i]

$\begin{array}{ll}\text { l } & \text { I } \\ \mathrm{H} & \mathrm{H}\end{array}$

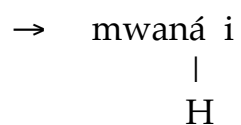

'which child'

(noun + enclitic)

(cf. munhu í ‘which

person')

(cf. bángá 'knife')

$\mathrm{H}$

Myers' view is that Shona provides evidence for the representation of the PW in (26b): MR would in this case apply only when the two $\mathrm{H}$ tones meet across a GW bracket.

Quite distinct from the Shona situation, MR applies throughout the prefix+stem word in Luganda (47a), but does not affect clitics $(47 b, c)$ :

(47) Meeussen's Rule applies throughout the prefix+stem word in Luganda, but not across clitics

a. [ a-ba- ta-li- $\left.\left[\text { tu- }[\text { lab-a }]_{\text {STEM }}\right]_{\mathrm{MS}}\right]_{\mathrm{W}}$

a-bá-tà-lì-tù-làb-a

$\begin{array}{ccccc}\text { I } & \text { I } & \text { I } & \text { | } & \text { । } \\ \text { H H } & \mathrm{H} & \mathrm{H} & \mathrm{H} \\ \downarrow & \downarrow & \downarrow & \downarrow \\ \text { L } & \mathrm{L} & \mathrm{L} & \mathrm{L}\end{array}$

IV-3pl-neg-fut-us-see-FV

'they who will not see us'

b. [né= $\left.[\text { kí-gùùndù }]_{\mathrm{PW}}\right]_{\mathrm{CG}}$

$\begin{array}{ll}\text { । } & \text { । } \\ \mathrm{H} & \underline{\mathrm{H}}\end{array}$

'with Kiguundu' c. [ [ a-sib-á $\left.]_{\mathrm{W}}=\mathrm{kô}\right]_{\mathrm{CG}}$

I I

$\mathrm{H} \quad \underline{\mathrm{H}}$

'he who ties a little' 
In this case we need to refer to the traditional Bantu word (prefixes + stem), which is supported by at least one other tonal fact. As seen in (48a), prefix+stem words can have one drop from H to L (' '), or they can be lexically toneless (48b):

(48) Prefix+stem words can have one drop from $\mathrm{H}$ to $\mathrm{L}$, or they can be lexically toneless

$\begin{array}{lllllll}\text { a. } & \text { ki-bê } & \text { 'jackal' } & \text { ki-sásìlo } & \text { 'rubbish' } & \text { ki-jîko } & \text { 'spoon' } \\ & \text { ki-kópò } & \text { 'cup' } & \text { ki-yulífù } & \text { 'torn' (cl.7) } & \text { ki-bínâ } & \text { 'society' } \\ \text { ki-sikî } & \text { 'log' } & \text { ki-wójjólò } & \text { 'butterfly' } & \text { ki-wúúgúlû 'owl' } \\ \text { ki-lókwâ } & \text { 'weed' } & \text { ki-bónèlezo } & \text { 'punishment' } & \text { ki-sáànikizo 'cover, lid' } \\ & \text { kí-kòlwa } & \text { 'deed' } & \text { ki-begábèga } & \text { 'shoulder' } & \text { ki-sáákáátè 'reed fence' } \\ \text { b. } & \text { ki-de } & \text { 'bell' } & \text { ki-tabo } & \text { 'book' } & \text { ki-tooke 'plantain tree' } \\ & \text { ki-bya } & \text { 'bowl' } & \text { ki-muli } & \text { 'flower' } & \text { ki-seenge 'room' } \\ & \text { ki-lagiro } & \text { 'command' } & \text { ki-biiliti 'match(-box)' } & \text { ki-sanilizo 'comb' } \\ & \text { ki-papajjo } & \text { 'branch' } & \text { ki-janjaalo 'bean' } & \text { 'ki-sumuluzo 'key' }\end{array}$

The latter words receive their output tones at the phrase level. In the following examples, the phrasal boundary tones \% L...H\% map as $\mathrm{LH}^{\mathrm{n}}$ (Hyman \& Katamba, in press):

(49) Phrasal \%L...H\% boundary tones map as $\mathrm{LH}^{*}$
a. kì-dé 'bell' kì-byá 'bowl'
kì-tábó 'book'
kì-múlí 'flower'
kì-tóóké 'plantain tree' kì-sééngé 'room'
b. kì-lágíró 'command'
kì-bíílítí 'match(-box)'
kì-jánjááló kì-pápájjó 'branch'
kì-sánílízó 'comb'
kì-súmúlúzó ' 'key'
c. $\% \mathrm{~L} H \%$
kì- pápájjó
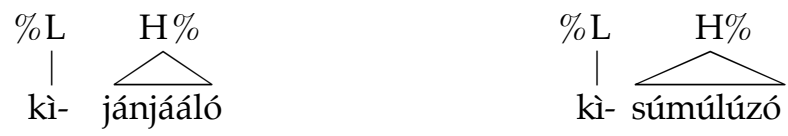

As seen in (49c), the \% $\mathrm{L}$ boundary tone links to the first vowel, and the final $\mathrm{H} \%$ boundary tone to the remaining toneless vowels.

By this criterion, the initial vowel augment (or preprefix) seen on the following nouns is a prefix:

(50) The initial vowel augment (preprefix) is a prefix
a. è-kí-dé 'bell'
è-kí-byá 'bowl'
è-kí-tábó 'book'
è-kí-múlí 'flower'
è-kí-tóóké 'plantain tree'
b. è-kí-lágíró 'command'
è-kí-bíílítí 'match(-box)'
è-kí-jánjááló 'bean'
è-kí-sééngé 'room'
è-kí-sánílízó 'comb'
è-kí-pápájjó 'branch'
è-kí-súmúlúzó ' key'

Just as the /H/ of the proclitic / né=/ did not trigger Meeussen's Rule in (47b), the mapping of boundary tones in (51) allows us to establish a criterion for distinguishing toneless proclitics from prefixes: 
(51) Proclitics are by this criterion not in the same PW

a. class $2 \mathrm{a} \mathrm{ba}=$

$$
\text { bà= kàtóndá ' 'gods' bà= Mùkásá 'the Mukasas' }
$$

b. locatives $\mathrm{ku}=($ class 17$)$ and $\mathrm{mu}=$ (class 18$)$

\begin{tabular}{|c|c|c|c|}
\hline $\begin{array}{l}\text { kù= kì-dé } \\
\text { kù= kì-tábó } \\
\text { kù= kì-sánízízó }\end{array}$ & $\begin{array}{l}\text { 'on the bell' } \\
\text { 'on the book' } \\
\text { 'on the comb' }\end{array}$ & $\begin{array}{l}\text { mù = kì-dé } \\
\text { mù = kì-tábó } \\
\text { mù = kì-sánízízó }\end{array}$ & $\begin{array}{l}\text { 'in the bell' } \\
\text { 'in the book' } \\
\text { 'in the comb' }\end{array}$ \\
\hline \multicolumn{4}{|c|}{ na $=$ 'with, and' (comitative, instrumental, associative) } \\
\hline $\begin{array}{l}\text { nà }=\text { kì-dé } \\
\text { nà= kì-tábó } \\
\text { nà = kì-sánízízó }\end{array}$ & $\begin{array}{l}\text { 'with a bell' } \\
\text { 'with a book' } \\
\text { 'with a comb' }\end{array}$ & $\begin{array}{l}\text { nà= Kàtóndá } \\
\text { nà= Mùkásá }\end{array}$ & $\begin{array}{l}\text { 'with God' } \\
\text { ‘with Mukasa' }\end{array}$ \\
\hline
\end{tabular}

d. genitive linker -aa=; here: / bi-aa/ 'those of' (class 8)
byàà = mù-ntú 'those of a person'
byàà = mù-límí 'those of a farmer'
byàà= Kàtóndá
'those of God'
byàà= mù-lámúzí 'those of a judge'
byàà= Mùkásá
'those of Mukasa'
(i.e. 'Mukasa's')

The toneless proclitics in question are plural class $2 \mathrm{a} b a=$, locative classes 17 and $18 \mathrm{ku}=\mathrm{and} \mathrm{mu}=$, na= 'with, and', and the genitive $-a a=$, which takes prefixal noun class agreement, e.g. class 8 byaa=. As seen, both they and the first syllable of the PW receive the $\% \mathrm{~L}$ tone.

The examples in (52) show that multiple proclitics will all link to the $\% \mathrm{~L}$ tone:

(52) Multiple proclitics show that each begins with a L (as does the base word)
a. kù= bà= kàtóndá 'on the gods' mù= bà= kàtóndá 'in the gods'
b. nà= kù= bà= kàtóndá
nà= byàà = bà= kàtóndá
byàà $=$ kù= bà $=$ kàtóndá
byàà= wàà $=$ bà $=$ kàtóndá
c. nà $=$ byàà $=$ kù $=$ bà $=$ kàtóndá
nà $=$ byàà $=$ wàà $=$ bà = kàtóndá 'with those of the one of the gods'
'and on the gods'
nà= bà= kàtóndá 'with the gods'
byàà= bà= kàtóndá 'those of the gods'
'with those of the gods'
'those on the gods'
'those of the one of the gods'
'with those on the gods'

In (53) two reasonable tree structures are presented which might account for the multiple realization of the initial \%L boundary tone:

(53) Two reasonable structures which might account for proclitic(s) + toneless base words

a.

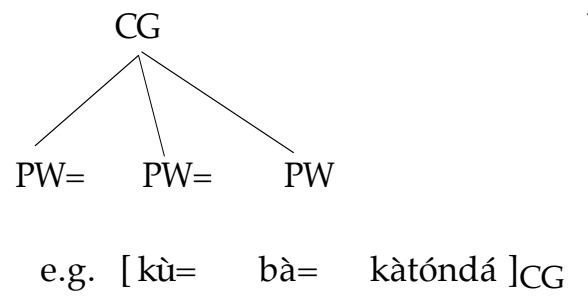

b.

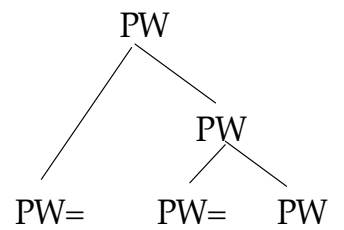

(53a) assumes a flat structure, while (53b) assumes a hierarchical structure with internal constituent structure and nested PWs. 
To summarize, there are two differences between Shona and Luganda: (i) Meeussen's Rule applies differently: $\mathrm{H}+\mathrm{H}$ must meet across a clitic-type boundary in Shona, whereas they must not in Luganda; (ii) Prefixes are different from proclitics in Luganda, whereas certain INFL prefixes appear equivalent to proclitics in Shona.

A third difference is that PWs are subject to a bisyllabic minimality condition in Shona (Myers 1995:87), but not in Luganda. Thus, in (46a), the subminimal, monosyllabic nouns /go/ acquire an epenthetic i- prefix to produce the required two syllables: ${ }^{20}$

(54) Minimality condition on words in Shona is satisfied by i-epenthesis (Myers 1987)
a. noun in isolation
b. with plural prefix
c. with proclitic
i-go 'wasp'
i-mbá 'house'
i-shé 'chief'
ma-go 'wasps'
dzi-mbá 'houses'
vá-she 'chiefs'
ne $=$ gó 'with a wasp'
$\mathrm{mu}=\mathrm{mbá} \quad$ 'in the house'
ndí= she '(he) is a chief'

Since the plurals have a prefix, there is no epenthetic i- in (54b), nor when the singulars are preceded by a proclitic in (54c). Again, we see the equivalence of proclitics and prefixes in Shona vs. their nonequivalence in Luganda.

The imperative forms in (55) show that enclitics never count towards satisfying the bisyllabic minimality requirement (Myers 1995:87-88):

(55) Enclitics never count towards the bisyllabic minimality requirement (cf. ku-pá 'give')
a. i-pá
'give!'
* pá
b. i-pá $=\mathrm{i}$
'give (pl.)!'
${ }^{*}$ pá $=\mathrm{i}$
c. i-pá =wo
'give please!'
*pá =wo
d. i-pá =zve
'give again!'
*pá $=$ zve
cf. Luganda wâ 'give!'

These facts suggest a left-branching PW tree, as in (56).

Left-branching PW tree in Shona

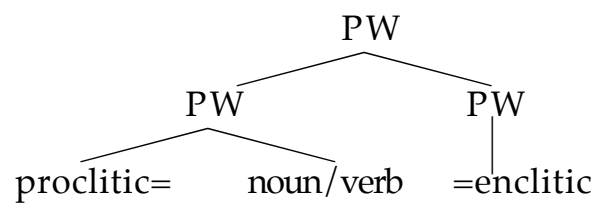

Luganda also requires that proclitics be more tightly bound to their hosts than enclitics. This of course contrasts with what was said about the tighter bond of prefixes vs. suffixes in (20).

A number of other $\mathrm{CB}$ languages, show similar bisyllabic word minimality conditions such as Kinande (Mutaka \& Hyman 1990), Chichewa (Kanerva 1989) and Ndebele (Downing 2001, Sibanda 
2004). Word minimality apparently is not found in NWB, which, as indicated in (57), has a quite different take on prosodic conditions:

Contrast between Central Bantu and Northwest Bantu

\section{Central Bantu}

Minimality conditions on words

Phrase-penultimate lengthening (> word)

Prefixes may interact with stem

\section{Northwest Bantu}

Maximality conditions on stems

Stem-initial strengthening (accent?)

Prefixes may be quite independent of stem

As we have just seen, certain CB languages place a bisyllabic minimality condition on words. Perhaps related, the penultimate syllable is often said to be prominent in CB. Most of the CB languages which have lost the inherited vowel length contrast lengthen vowels in phrase-penultimate position. (Some narrow this to smaller domains, ultimately the word.) One thinks not only of penultimate stress in Standard Swahili (which has lost its tone), but also languages such as Chizigula, where, as seen in (58b), a $\mathrm{H}$ prefixal tone is attracted to penultimate position (unmarked vowels $=\mathrm{L}$ tone):

(58) Tonal attraction to penultimate accent in Chizigula (Kenstowicz \& Kisseberth 1990:171)

a. na-ku-gulusa 'I am chasing you' vs. b. a-ku-gulúsa 'he is chasing you'

Finally, as we saw in the application of MR in Luganda in (47a), prefixes may interact with the stem phonologically in $\mathrm{CB}$, while their independence from the stem was seen in both Basaa and Kukuya in $\S 5.1$.

To summarize this section, we have seen that the word is more varied and elusive within Bantu, as perhaps also outside. Other than the asymmetry between proclitics vs. enclitics indicated in (56), we have also found it harder to establish asymmetries of the sort seen in earlier sections, particularly as characterizing P-stems (§5.1). The examples in (49)-(52) show that it is possible on the basis of tone to distinguish between prefixes and proclitics in Luganda. ${ }^{21}$ However, there do not appear to be segmental differences between what is a possible prefix vs. proclitic in Bantu. In the final section I briefly consider the sometimes special prefix-stem phonology found in and outside Bantu.

\section{Prefix-stem fusion}

In the preceding sections an attempt has been made to synthesize some of the generalizations that have been demonstrated or claimed concerning directional asymmetries: languages tend to prefer suffixation 
over prefixation, segmental assimilations tend to be more anticipatory than perseverative, and strengthening (preservation) and weakening (loss) affect stem-initial and word-final positions, respectively.

A number of explanations have been proposed to account for the claimed generalizations. Smith (2002) proposes that MWord initials are "psycholinguistically strong" because of the importance of initials in early word recognition. Lexical accessing would thus be greatly enhanced if the beginnings of lexical morphemes were clearly demarcated, either segmentally or prosodically (e.g. by stress). The logical endpoint of such a strategy would be to disallow prefixation such that every word begins with a root morpheme. Specifically, prefixes and roots should exhibit a resistance to fusion-rather than a tendency to fuse, as claimed by Greenberg's (1957), cited in §2.2. While the notion of ex-prefixation was introduced in \$5.1, whereby a prefix separates prosodically from its stem, a contradictory tendency was also seen, e.g. in Basaa in $§ 3.3$, where a CV prefix fuses with a vowel-initial root to become part of the stem. $^{22}$

There are, in fact, two kinds of prefix+stem fusion, both of which obscure prefix-stem demarcation. The first occurs when properties of the prefix are incorporated into the following root. This may occur when the root is vowel-initial, as in Basaa, or consonant-initial, as in the following examples from Tuki, another NWB language:

(59) Prefix features incorporated into stem in Tuki (Hyman 1992)

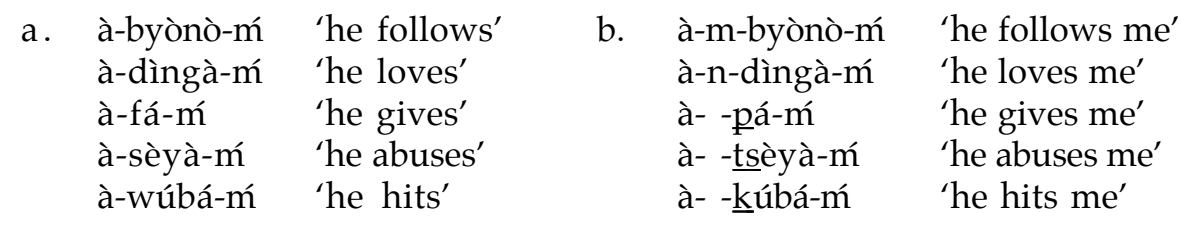


The forms in (59b) show that the first person object nasal prefix is realized as a nasal before voiced stops, but fuses with the stem-initial continuants /f, s, w/. Numerous Bantu, Austronesian, and other languages restrict various types of $\mathrm{N}+\mathrm{C}$ modifications to the prefix-stem boundary. Since some of these processes involve deletion of the post-nasal stem-initial consonant, it is unlikely that they are designed to enhance the early recognition of the prefix-stem boundary. ${ }^{23}$

The second kind of prefix+stem fusion occurs when features of the root are anticipated onto the prefix. A dramatic example of this occurs in Esimbi. As seen in (60a), the vowel height features of the root shift onto the prefix, here the class 3 archiphoneme /U-/:

(60) Stem features incorporated into prefix in Esimbi (Stallcup 1980, Hyman 1988).

\begin{tabular}{|c|c|c|c|c|c|c|}
\hline $\begin{array}{l}\text { /U-mu/ } \\
\text { /U-mo/ } \\
\text { /Ú-mo/ }\end{array}$ & $\begin{array}{l}\rightarrow \\
\rightarrow \\
\rightarrow\end{array}$ & $\begin{array}{l}\text { [u-mu] } \\
{[\text { o-mu] }} \\
\text { [ó-mu] }\end{array}$ & $\begin{array}{l}\text { 'to drink' } \\
\text { 'to go up' } \\
\text { 'to sit' }\end{array}$ & $\begin{array}{l}\text { /U-wu/ } \\
\text { /U-wǒ / } \\
\text { /U-wǒ / }\end{array}$ & 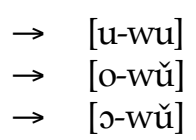 & $\begin{array}{l}\text { 'uproot' } \\
\text { 'burn (intr.)' } \\
\text { 'grind' }\end{array}$ \\
\hline $\begin{array}{l}\text { /U-tana / } \\
\text { /U-gaba / }\end{array}$ & $\rightarrow$ & $\begin{array}{l}{[0-t+1 j i]} \\
{[0-g i b i]}\end{array}$ & $\begin{array}{l}\text { 'to count' } \\
\text { 'to divide' }\end{array}$ & $\begin{array}{l}\text { cf. Proto-Bantu } \\
\text { cf. Proto-Bantu }\end{array}$ & $\begin{array}{l}\text { *-táy- } \\
\text { *-gàb- }\end{array}$ & \\
\hline
\end{tabular}

The examples in (60b) further demonstrate that stem vowels must be both high and identical. As in the case of infixation (§3.2), a stem property is realized "out of order". However, it is difficult to argue that anticipation of vowel height is an aid to early stem recognition when the stems themselves are obscured by the high vowel restriction. While Stallcup hypothesizes that the prefix is accented, this still doesn't explain why Esimbi doesn't simply have anticipatory vowel harmony.

Among the evidence cited by Smith (2002) for word-initial prominence are languages which require a word-initial syllable to have an onset. The Niger-Congo languages I have studied that have this property also require a stem-initial syllable to have an onset, e.g. Gokana. In Ndebele, a monosyllabic stem or reduplicant will acquire an epenthetic syllable [yi] to fill out the bisyllabic minimality condition, e.g. / dla/ 'eat' $\rightarrow$ [yidla] 'eat!', [dlayi-dla] 'eat here and there!' (Hyman, Inkelas \& Sibanda 1998, Downing 2001, Sibanda 2004). Since Ndebele also has CV prefix fusion (Sibanda 2004), the correct generalization is that a stem vowel must co-occur with an onset consonant.

The above examples and brief discussion suggest that stem-initial phonology has little, if anything, to do enhancing early stem- or word recognition as an aid to the listener. On the positive 
side, the phenomena examined in this paper are compatible with the notion that speakers show priority to stems in lexical accessing and production. Perhaps for their own benefit, speakers preserve, strengthen, and anticipate early stem properties, which are made all the earlier by favoring suffixes over prefixes. Such a view is most compatible with the directional- and edge-asymmetries documented above within Bantu and other morphological and phonological systems. It will, however, be crucial to see if the oft-claimed preferences hold up against further testing and a broader, perhaps more systematic database.

\section{References}

Akinlabi, Akinbiyi (1996) Featural affixation. Journal of Linguistics 32.239-289.

Alderete, John D (2001a). Dominance effects as transderivational anti-faithfulness. Phonology 18.201253.

Alderete, John D. (2001b). Morphologically governed accent in optimality theory. New York: Routledge. [Revised 1999 Doctoral dissertation, University of Massachusetts, Amherst]

Bakovic, Eric (2000). Harmony, dominance and control. PhD dissertation. Rutgers University.

Barnes, Jonathan Allen (2002). Positional neutralization: a phonologization approach to typological patterns. Doctoral dissertation, University of California, Berkeley.

Barreteau, D.; and Le Bléis, Y. (1987). Lexèmes et thèmes verbaux en mafa. In Cahiers du LACITO 2, 3152. Paris: CNRS.

Barreteau, D. \& Le Bléis, Y. (1990). Lexique Mafa: langue de la famille tchadique parlée au Cameroun. Etudes Tchadiques Monographies. Paris: Editions de l'ORSTOM.

Beckman, Jill (1998). Positional faithfulness. Doctoral dissertation, University of Massachusetts, Amherst.

Bickel, Balthasar (in press). Prosodic tautomorphemicity in Sino-Tibetan. In David Bradley, Randy J. LaPolla \& Graham Thurgood (eds), Language variation: papers on variation and change in the Sinosphere and Indosphere in honour of James A. Matisoff. Canberra: Pacific Linguistics.

Blanchon, Jean (1995). Punu lexical database in Filemaker Pro ${ }^{\mathrm{TM}}$.

Booij, Geert E. (1983). Principles and parameters in prosodic phonology. In Explanations for language universals, Brian Butterworth, Bernard Comrie, and Östen Dahl (eds), 249-280. Berlin: Mouton. 
Borowsky, Toni (2000). Word-faithfulness and the direction of assimilation. The Linguistic Review 17.1-28.

Bybee, Joan L.; Chakraborti, Paromita; Jung, Dagmar; and Scheibman, Joanne. 1998. Prosody and segmental effect: some paths of evolution for word stress. Studies in Language 22.267-314.

Bybee, Joan L.; Pagliuca, William; and Perkins, Revere D. (1991). On the asymmetries in the affixation of grammatical material. In Studies in typology and diachrony, William Croft, Keith Denning and Suzanne Kemmer (eds.), 1-42. Amsterdam: Benjamins.

Casali, Roderic (1997). Vowel elision in hiatus contexts: which vowel goes? Language 73.493-533.

Chen, Matthew (1987). The syntax of Xiamen tone sandhi. Phonology [Yearbook] 4.109-149.

Clements, G.N. (1981). Akan vowel harmony: A non-linear analysis. Harvard Studies in Phonology 2.108-177.

Davy, J. I. M.; and Derek Nurse (1982). Synchronic versions of Dahl's Law: The multiple applications of a phonological dissimilation rule. Journal of African Languages \& Linguistics 4.157-195.

Downing, Laura J. (1999). Prosodic stem $\neq$ prosodic word in Bantu. In Hall \& Kleinhenz, 73-98.

Downing, Laura J. (2001). Ungeneralizable minimality in Ndebele. Studies in African Linguistics 30.3358.

Downing, Laura J. (2005). On the ambiguous segmental status of nasals in homorganic NC sequences. In The internal organization of phonological segments, Marc van Oostendorp \& Jeroen van de Weijer (eds.), 183-215. Berlin: Mouton de Gruyter.

Enrique-Arias, Andrés (2002). Accounting for the position of verbal agreement morphology with psycholinguistic and diachronic explanatory factors. Studies in Language 26.1-31.

Ettlinger, Marc (2004). Aspect in Mafa: An Intriguing Case of Featural Affixation. In Proceedings of the 40th Meeting of the Chicago Linguistics Society (CLS 40), F. Parrill, T. Weir, and N. Adams (eds.). Chicago, IL: Chicago Linguistic Society (in press).

Fontaney, Louise (1980). Le verbe. In Eléments de description du punu, F. Nsuka-Nkutsi (ed.), 51-114. CRLS, Université Lyon2.

Greenberg, Joseph H. (1957). Essays in linguistics. Chicago: University of Chicago Press. 
Greenberg, Joseph H. (1966). Some universals of grammar with particular reference to the order of meaningful elements. In Universals of language, Joseph H. Greenberg (ed.), 73-113. Cambridge, MA: MIT Press.

Hall, Beatrice L.; and Hall, R.M.R. (1980). Nez Perce vowel harmony: an Africanist explanation and some theoretical questions. In Issues in vowel harmony, Robert M. Vago (ed.), 201-236. Amsterdam: Benjamins.

Hall, Christopher. 1988. Integrating diachronic and processing principles in explaining the suffixing preference. In Hawkins, 321-349.

Hall, T. Alan; and Kleinhenz, Ursula (eds.) (1999). Studies on the phonological word. Amsterdam: Benjamins.

Hansson, Gunnar Ólafur (2001). Theoretical and typological issues in consonant harmony. Doctoral dissertation, University of California, Berkeley.

Hawkins, John A. (ed.) (1988). Explaining language universals. Oxford: Blackwell.

Hawkins, John A.; and Cutler, Anne (1988). Psycholinguistic factors in morphological asymmetry. In Hawkins, 280-317.

Hawkins, John A.; and Gilligan, Gary (1988). Prefixing and suffixing universals in relation to basic word order. In Papers in universal grammar: generative and typological approaches, John A. Hawkins and Heather K. Holmback (eds.), 219-259. Lingua 74:219-259.

Hayes, Bruce (1987). Precompiled phrasal phonology. In Sharon Inkelas \& Draga Zec (eds), The phonology-syntax connection, 85-108. University of Chicago Press.

Hayes, Bruce (1995). Metrical stress theory: principles and case studies. Chicago: University of Chicago Press.

Hyman, Larry M. (1975). Phonology: theory and analysis. New York: Holt, Rinehart \& Winston.

Hyman, Larry M. (1977). On the nature of linguistic stress. In Studies in Stress and Accent (Southern California Occasional Publications in Linguistics 4), Larry M. Hyman (ed.), 37-82. University of Southern California.

Hyman, Larry M. (1981). Noni grammatical structure. Southern California Occasional Papers in Linguistics (SCOPIL) 9, University of Southern California. 
Hyman, Larry M. (1987). Prosodic domains in Kukuya. Natural Language and Linguistic Theory 5.311333.

Hyman, Larry M. (1988). Underspecification and vowel height transfer in Esimbi. Phonology 5.255-273.

Hyman, Larry M. (1995). Nasal consonant harmony at a distance: the case of Yaka. Studies in African Linguistics 24.5-30.

Hyman, Larry M. (1998). Positional prominence and the 'prosodic trough' in Yaka. Phonology 15.41-75.

Hyman, Larry M. (1999). The historical interpretation of vowel harmony in Bantu. In Bantu historical linguistics: Theorical and empirical perspectives, Jean-Marie Hombert and Larry M. Hyman (eds), 235-295. Stanford: C.S.L.I.

Hyman, Larry M. (2001). On the limits of phonetic determinism in phonology: ${ }^{*} \mathrm{NC}$ revisited. In The Role of Speech Perception Phenomena in Phonology, Beth Hume \& Keith Johnson (eds), 141-185. Academic Press.

Hyman, Larry M. (2003a). Segmental phonology. In Nurse \& Philippson, 42-58.

Hyman, Larry M. (2003b). Basaa A.43. Nurse \& Philippson, 257-282.

Hyman, Larry M. (2004). How to become a Kwa verb." Journal of West African Languages 30.69-88

Hyman, Larry M. (in press). Is there a right-to-left bias in vowel harmony?" In Phonologica 2002, John R. Rennison, Friedrich Neubarth and Markus A. Pochtrager (eds.). Berlin: Mouton.

Hyman, Larry M.; and Biloa, Edmond (1992). Transparent low tone in Tuki". In Special Session on the Typology of Tone Languages, Laura A. Buszard-Welcher et al (eds.), 104-127. Berkeley Linguistic Society 18.

Hyman, Larry M; Inkelas, Sharon; and Galen Sibanda (1998). Morphosyntactic correspondence in Bantu reduplication. In K. Hanson \& S. Inkelas (eds), The nature of the word: Essays in Honor of Paul Kiparsky. MIT Press (to appear, 2005).

Hyman, Larry M.; and Katamba, Francis X. (in press). The word in Luganda. In Proceedings of Cologne Conference on Typology, Erhard Voeltz (ed.), June 2001.

Hyman, Larry M. \& Russell G. Schuh (1974). Universals of tone rules: evidence from West Africa. Linguistic Inquiry 5.81-115.

Inkelas, Sharon (1989). Prosodic constituency in the lexicon. Doctoral dissertation, Stanford University. New York: Garland Press, 1990. 
Inkelas, Sharon (1996). Dominant affixes and the phonology-morphology interface. In Interfaces in phonology, Ursula Kleinhenz (ed.), 128-154. Akademie Verlag.

Inkelas, Sharon (1998). The theoretical status of morphologically conditioned phonology: a case study of dominance effects. In Geert Booij and Jaap van Marle (eds.), Yearbook of Morphology 1997, 121155. Kluwer.

Inkelas, Sharon \& Cheryl Zoll (2005). Reduplication: Doubling in Morphology. Cambridge University Press.

Kanerva, Jonni (1989). Focus and phrasing in Chichewa phonology. Doctoral Dissertation, Stanford University.

Katamba, Francis X.; and Hyman, Larry M. (1991). Nasality and morpheme structure constraints in Luganda. Africanistische Arbeitspapiere 25.175-211.

Kenstowicz, Michael; and Kisseberth, Charles (1990). Chizigula tonology: the word and beyond. In The phonology-syntax connection, Sharon Inkelas \& Draga Zec (eds.), 163-194. University of Chicago Press.

Kiparsky, Paul (1982). Lexical morphology and phonology. In Linguistics in the morning calm, I.-S. Yang (ed.), 3-91. Seoul: Hanshin.

Kiparsky, Paul (2000). Opacity and cyclicity. The Linguistic Review 17.351-367.

McCarthy, John J. (1983). Consonantal morphology in the Chaha verb. Proceedings of West Coast Conference on Formal Linguistics 2.176-188.

Meeussen, A.E. (1961). Le ton des extensions verbales en bantou. Orbis 10.424-427.

Meeussen, A.E. (1967). Bantu grammatical reconstructions. Africana Linguistica 3.81-121. Annales du Musée Royale de l'Afrique Centrale. Série IN-8, Sciences Humaines. N. 121. Tervuren.

Meeussen, A.E. (1969) [1980]. Bantu lexical reconstructions. Tervuren: Musée Royal de l'Afrique Centrale.

Meinhof, C.; and van Warmelo, N.J. (1932). Introduction to the phonology of the Bantu languages. Berlin: Dietrich Reimer.

Mutaka, Ngessimo; and Hyman, Larry M. (1990). Syllables and morpheme integrity in Kinande reduplication. Phonology 7.73-119. 
Myers, Scott (1987). Tone and the structure of words in Shona. Doctoral dissertation, University of Massachusetts, Amherst.

Myers, Scott (1995). The phonological word in Shona. In Francis Katamba (ed.), Bantu phonology and morphology, 69-92. Munich: LINCOM.

Myers, Scott (1998). AUX in Bantu morphology and phonology. In Theoretical aspects of Bantu tone, Larry M. Hyman \& Charles W. Kisseberth (eds), 231-264. Stanford: C.S.L.I.

Nelson, Nicole (2002). The "prefixing" preference in reduplication. Proceedings of the West Coast Conference on Formal Linguistics 21.320-333.

Nespor, Marina; and Vogel, Irene (1986). Prosodic phonology. Dordrecht: Foris.

Ngunga, Armindo (2000). Phonology and morphology of the Ciyao verb. Stanford: C.S.L.I.

Nooteboom, S. G (1981). Lexical retrieval from fragments of spoken words: beginnings vs. endings. Journal of Phonetics 9.407-424.

Nurse, Derek; and Philippson, Gérard (2003a). Introduction. In Nurse \& Philippson, 1-12.

Nurse, Derek; and Philippson, Gérard (eds). (2003b). The Bantu languages. London: Routledge/Curzon.

Ohala, John J. (1990). The phonetics and phonology of aspects of assimilation. In Papers in laboratory phonology I: between the grammar and physics of speech, John Kingston \& Mary Beckman (eds), 258275. Cambridge University Press.

Paulian, Christiane (1975). Le kukuya: langue teke du Congo. Paris: SELAF.

Plank, Frans (1998). The co-variation of phonology with morphology and syntax: A hopeful history. Linguistic Typology 2.195-230.

Raffelsiefen, Renate (1999). Diagnostics for prosodic words revisited: The case of historically prefixed words in English. In Hall \& Kleinhenz, 133-201.

Rankin, Robert; Boyle, John; Graczyk, Randolph; and Koontz, John.. 2002. Synchronic and diachronic perspective on 'word' in Siouan. In Word: A cross-linguistic typology R.M.W. Dixon \& Alexandra Y. Aikhenvald (eds), 180-204. Cambridge University Press.

Rose, Sharon (1993). Palatalization, underspecification, and plane conflation in Chaha. Proceedings of WCCFL 12.

Russell, Kevin (1999). The "word" in two polysynthetic languages. In Hall \& Kleinhenz, 203-221. 
Ruttenberg, S.J. Piet (1971) [2000]. Lexique yaka-français, français-yaka. Kinshasa. Reprinted, Munich: Lincom.

Sapir, Edward (1921). Language. New York: Harcourt, Brace \& World.

Selkirk, Elisabeth O. (1980). Prosodic domains in phonology: Sanskrit revisited. In Juncture, Mark Aronoff \& Mary-Louise Kean (eds), 107-129. Saratoga, CA: Anma Libri.

Selkirk, Elisabeth O. (1984). Phonology and syntax: the relation between sound and structure. Cambridge, MA: MIT Press.

Selkirk, Elisabeth O. (1986). On derived domains in sentence phonology. Phonology [Yearbook] 3.371405.

Sibanda, Galen (2004). Verbal phonology and morphology of Ndebele. Doctoral dissertation, University of California, Berkeley.

Smith, Jennifer L. (2002). Phonological augmentation in prominent positions. Doctoral dissertation, University of Massachusetts, Amherst.

Stallcup, Kenneth L. (1980). Noun classes in Esimbi. In Noun classes in the Grassfields Bantu borderland, Larry M. Hyman (ed.), 139-153. Southern California Occasional Papers in Linguistics 8. Los Angeles: University of Southern California.

Steriade, Donca (2001). Directional asymmetries in place assimilation: A perceptual account. In The role of speech perception in phonology, Elizabeth Hume \& Keith Johnson (eds), 219-250. New York: Academic Press.

Stevick, E. W. (1969). Tone in Bantu. IJAL 35.330-341.

Suzuki, Keiichiro (1998). A typological investigation of dissimilation. Doctoral dissertation, University of Arizona.

Teil-Dautrey, Gisèle (2004). Lexiques proto-bantous: étude des cooccurrences segmentales et suprasegmentales. Doctoral dissertation, Université de Lyon2.

Wennerstrom, Ann (1993). Focus on the prefix: evidence for word-internal prosodic words. Phonology 10.309-324.

Zoll, Cheryl (1998). Parsing below the segment in a constraint-based framework. Stanford: CSLI. 
${ }^{1}$ This paper was presented at the Workshop on Word Domains: Theory and Typology, University of Leipzig, April 7-8, 2004. I would like to thank Balthasar Bickel, Tracy Hall, and Kristine Hildebrandt for their invitation, hospitality, and intellectual exchanges both during and at the edges of the workshop. I am also endebted to two anonymous reviewers for their suggestions for revision.

${ }^{22}$ In Hyman (1975:222) tone spreading is referred to as "horizontal assimilation" and register adjustment as "vertical assimilation". Rather than a perseverative bias, the latter shows a pitch gesture asymmetry: / L-H/ frequently becomes $[\mathrm{M}-\mathrm{H}]$ by anticipatory raising or [L-M] by perseverative lowering, but / H-L/ does not readily become [M-L] or [H-M]. Instead, there is a strong tendency to raise a $\mathrm{H}$ tone to superhigh when followed by $\mathrm{L}$. The generalization is that the interval from $\mathrm{L}$ to $\mathrm{H}$ tends to compress, while the interval from $\mathrm{H}$ to $\mathrm{L}$ tends to expand.

${ }^{3}$ The expected form * nokod is instead realized [nok $\left.{ }^{\mathrm{w} a d}\right]$, since [o] is restricted after velars in Mafa.

${ }^{4}$ While I have not done a systematic study, and although both are found, it is my impression that suffixal tones also tend to be more readily incorporated to form stem melodies than prefixal tones. Similarly, postposed lexical floating tones are more robustly attested than preposed: Aghem /-fú/ 'rat' vs. /-wó $/$ 'hand'. Although this can be attributed to the loss of the final syllable (cf. Proto-Bantu *-bókò 'arm, hand'), it is significant that lexical representations such as /-' bò/ are quite rare.

${ }^{5}$ As discussed in Hyman (in press), tone is not subject to root control.

${ }^{6}$ This is particularly true in the case of vowel harmony: “...there seem to be no true cases of Dominant grammatical prefixes which cause harmony to themselves. Apparent counterexamples... are clearly compounds...." (Hall \& Hall 1980:227n).

${ }^{7}$ A number of studies use the term "stem-control" instead of "root control", e.g. Bakovic (2000) and Hansson (2001). Since I need the term "stem" to refer to root+suffixes in §5, I will retain "root-control" here, recognizing that control may be from the root or some combination of root+affixes.

${ }^{8}$ These statements specifically pertain to situations where the harmonizing feature originates in P1, $\mathrm{P} 2, \mathrm{~S} 1$ or S2, not where prefixes or suffixes pass on a feature which originates in the root.

${ }^{9}$ Russell (1999) analyzes Dakota as (20b). However, see Rankin, Boyle, Graczyk \& Koontz (2002), who discuss the difficulty in determining whether Siouan has suffixes vs. enclitics. 
${ }^{10}$ Bybee et al hypothesize that this has to do with the greater number of verb-final languages, which, given the natural pathways for grammaticalization, tend to produce suffixes.

${ }^{11}$ The discussion in this section concerns verbs in Bantu, since they have a more complex morphological structure. As Thilo Schadeberg (pers.comm.) reminds me, the base taam- in (21) is itself historically complex, deriving from *tá- 'put' + *-am-, a frozen positional extension meaning 'be in a position', hence *tá-am- 'be put'.

${ }^{12}$ Proto-Bantu also had voiceless prenasalized consonants. Since these are less numerous in general, I have omitted them from the table. $C_{1} / C_{2}$ numbers are: *mp $(\varnothing / 2),{ }^{*} \mathrm{nt}(1 / 8),{ }^{*} \mathrm{nc}(2 / \varnothing),{ }^{*} \mathrm{yk}(1 / 9)$; there are $\varnothing$ occurring in $C_{3}$ position.

${ }^{13}$ Meeussen reconstructs ${ }^{*} \mathrm{H} /{ }^{*} \mathrm{~L}$, but another interpretation of ${ }^{*} \mathrm{~L}$ is ${ }^{*} \varnothing$ (cf. Stevick 1969).

${ }^{14}$ Hyman (2004) argues that such prosodic maximality conditions enhance the development of alternative analytic constructions, as West African languages replace head-marking on the verb with dependent-marking on the noun phrase.

${ }^{15}$ Stops may also be devoiced before pause. The noun written mùd 'person' is variably pronounced [mùd], [mùr] or [mùt].

${ }^{16}$ When class 8 / Pì-/ fuses with a vowel-initial root, the result however is voiced: / Pì-óm/ $\rightarrow$ [gw̌m ] 'things' (cf. / Pì-tón/ $\rightarrow$ [bì-tón] 'horns'). This may be because there is a contrastive / $\mathrm{k}^{\mathrm{w}} /$ in Basaa.

${ }^{17}$ Basaa also restricts the combination of $C_{2}, C_{3}$ and $C_{4}$ consonants. See Hyman (2003b).

${ }^{18}$ Another frequent stratum 1 process is the coalescence of ${ }^{*} \mathrm{a}+{ }^{*} \mathrm{i}$ to [ee]. This occurs, for instance, when the perfective suffix -il- is "imbricated", as in Cibemba: / ísal-il-e/ $\rightarrow$ ísail-e $\rightarrow$ [íseel-e] 'close (tr.) + perfective'. In this case, Ca- noun prefixes also join the stem, e.g. Ciyao /ma-ísó/ $\rightarrow$ [méésó] 'eyes'. In all other situations, including Ca- verb prefixes, / $\mathrm{a}+\mathrm{i} /$ is realized [ii]. For an overview of Bantu segmental phonology, see Hyman (2003a).

${ }^{19}$ The macrostem is a Bantu-specific domain consisting of an object prefix + verb stem. Where MR does not apply, e.g. between a $\mathrm{H}$ tone subject prefix $+\mathrm{a} \mathrm{H}$ verb root in the subjunctive, Myers assigns both to an extended notion of macrostem. Historically, MR did not apply to * $\mathrm{H}$ tones in sequence. All of Myers' examples involve forms where a mora with L tone has been lost, e.g. future *kí-à- > [čá], *ì-pánga > 
[bángá] 'knife'. The process was one of creating downsteps, followed by lowering: * $\mathrm{H}-\mathrm{L}-\mathrm{H}>\mathrm{H}-{ }^{\prime} \mathrm{H}>\mathrm{H}-$ L. By losing these L tone-bearing units, we are left with a synchronic situation where / H-H/ sometimes undergoes MR, sometimes does not.

${ }^{20}$ From an historical perspective, one could argue that class 5 and $9{ }^{*}{ }^{i-}$ was retained only when needed to satisfy the bisyllabic minimality requirement.

${ }^{21}$ Similarly, enclitics can be distinguished from suffixes on the basis of their tonal behavior.

${ }^{22}$ One might propose that the CV prefix provides an obligatory onset to the stem. Note, however, that many stems begin with a vowel on the surface, e.g. [éc] 'tree', [óó] 'ear'.

${ }^{23}$ Katamba \& Hyman (1991) show that in Luganda Meinhof's Rule will simplify a nasal + voiced stop to a geminate nasal only if the voiced stop belongs to the stem. The rule thus applies not only between a nasal prefix and stem $C_{1}$, but also to a nasal + voiced stop appearing totally within the stem. Meinhof's Rule will not apply if the nasal prefix is followed by a prefix beginning with a voiced stop. 